\title{
The Atlantic Deep Western Boundary Current: Water masses and transports near the equator
}

\author{
Monika Rhein, Lothar Stramma, and Uwe Send \\ Regionale Oceanographie, Institut für Meereskunde an der Universität Kiel, Kiel, Germany
}

\begin{abstract}
The distributions and transports of deepwater masses at the western boundary in the tropical Atlantic off Brazil have been studied on three surveys along $35^{\circ} \mathrm{W}$ and $5^{\circ} \mathrm{S}$ and one at $10^{\circ} \mathrm{S}$. Transports are obtained from direct measurements of the velocity fields (Pegasus profiling system and lowered acoustic Doppler current profiler) and from geostrophic computations. Using chlorofluoromethane (CFM) and hydrographic distributions, four water masses could be identified forming the North Atlantic Deep Water (NADW) system. Two of these have a high CFM content, the "shallow upper NADW" (SUNADW) and the "overflow lower NADW" (OLNADW). These exhibit the highest velocity signals at $35^{\circ} \mathrm{W}$, where distinct flow cores seem to exist; most of the southeastward flow of the SUNADW (centered around $1600 \mathrm{~m}$ ) occurs $320 \mathrm{~km}$ offshore between $3^{\circ} 09^{\prime} \mathrm{S}$ and $1^{\circ} 50^{\prime} \mathrm{S}(9.7 \pm 3.3 \mathrm{~Sv})$; farther north in that section, a highly variable reversing flow is found in a second velocity maximum. The transport of OLNADW (centered around $3800 \mathrm{~m}$ ) of $4.6 \pm 2.6 \mathrm{~Sv}$ is guided by the Parnaiba Ridge at $1^{\circ} 45^{\prime} \mathrm{S}, 35^{\circ} \mathrm{W}$. The water masses located between the two CFM maxima, the Labrador Sea Water (LSW) and the LNADW old water mass (LNADWold), did not show any persistent flow features, however, a rather constant transport of $11.1 \pm 2.6 \mathrm{~Sv}$ was observed for these two layers. The total southeastward flow of the NADW at $35^{\circ} \mathrm{W}$ showed a transport of $26.8 \pm 7.0 \mathrm{~Sv}$, if one neglects the reversing SUNADW north of $1^{\circ} 50^{\prime} \mathrm{S}$. At $5^{\circ} \mathrm{S}$ the flow of all deepwater masses shows vertically aligned cores; the main southward transport occurred near the coast $(19.5 \pm 5.3 \mathrm{~Sv})$. The boundary current is limited offshore by a flow reversal, present in all three surveys, but located at different longitudes. At $10^{\circ} \mathrm{S}$ a southward transport of $4.7 \mathrm{~Sv}$ was observed in November 1992 . However, the section extended only to $32^{\circ} 30^{\prime} \mathrm{W}$, so that probably a significant part of the flow has been missed. An important result is the large transport variability between single cruises as well as variability of the spatial distribution of the flow at $35^{\circ} \mathrm{W}$, which could lead to large uncertainties in the interpretation of single cruise observations. Despite these uncertainties we suggest a circulation pattern of the various deepwater masses near the equator by combining our mean transport estimates with other observations.
\end{abstract}

\section{Introduction}

The Deep Western Boundary Current (DWBC) in the North Atlantic Ocean is a major component of the global oceanic thermohaline circulation and is important not only for interhemispheric water mass exchange, but also for the meridional heat flux. Flowing along the continental margin of the American continent, the DWBC transports water from northern origin to the south across the equator below about $1200 \mathrm{~m}$, whereas in shallower layers a reverse flow of warmer, southern origin water occurs. The near-bottom flow is also northward and carries Antarctic Bottom Water $(A A B W)$ into the northern hemisphere.

In the western boundary regime of the tropical Atlantic the layer of warm, saline, and oxygen rich water of northern origin (North Atlantic Deep Water (NADW)) extends from about $1200 \mathrm{~m}$ to $4000 \mathrm{~m}$ depth. The contributions to NADW come from various sources, and NADW has been separated in the literature into one to three water masses [e.g.,

Copyright 1995 by the American Geophysical Union.

Paper number 94JC02355.

0148-0227/95/94JC-02355\$05.00
Sverdrup et al., 1942; Tchernia, 1980]. Recently, measurements of the anthropogenic tracers tritium and chlorofluoromethanes (CFMs) lead to a distinction of two water types within the upper part of the NADW, yielding a total of four separate NADW components [Pickart, 1992]. The northward flow of AABW below the NADW originates partly from deepwater formed in the Weddell Sea and partly from the Circumpolar Current.

Mainly owing to lack of direct velocity data and the difficulties in using geostrophic computations near the equator, estimates of the DWBC transport crossing the equator are sparse. Reported estimates in the general area of the tropical Atlantic, evaluated from geostrophic computations, but also from current meter moorings, are of the order of 17-25 Sv of NADW flowing toward and across the equator [Speer and McCartney, 1991; Molinari et al., 1992; Schott et al., 1993; Schmitz and McCartney, 1993]. The observed transports are higher than the estimates derived from inverse calculations (about 10-15 Sv; [Bryden and Hall, 1980; Roemmich, 1980; Hall and Bryden, 1982; Wunsch and Grant, 1982]).

It was the aim of the R $V$ Meteor cruises MI4/2 (October 


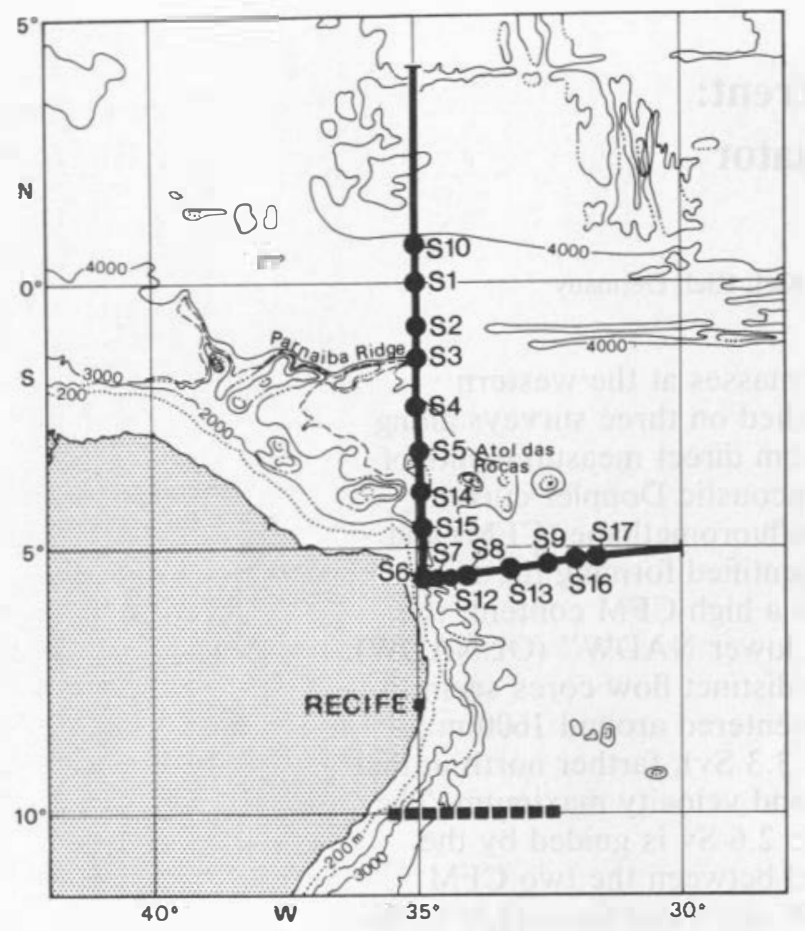

Figure 1. Conductivity-temperature-depth (CTD) and lowered acoustic Doppler current profiler (LADCP) sections (thick, solid lines) and Pegasus stations (S1-S17) (solid circles) used in this paper for October 1990 (M14), May-June 1991 (M16), and November 1992 (M22). The CTD section at $10^{\circ} \mathrm{S}$ was only occupied in November 1992. The isobaths plotted are 200, 2000, 3000, and $4000 \mathrm{~m}$, except for an additional $3500-\mathrm{m}$ isobath at the Parnaiba Ridge. This ridge turned out to be important for the deepwater flow.

1-27, 1990), M16/3 (May 23 to June 17, 1991), and M22/2 (October 23 to November 16, 1992) to study water mass distributions and transports crossing the equator in the DWBC based on hydrographic and oxygen data, direct velocity measurements (Pegasus profiling system and lowered acoustic Doppler current profiler, LADCP) as well as measurements of the two CFMs FII and F12. The measurements were carried out on two meridional sections $\left(44^{\circ} \mathrm{W}\right.$, $35^{\circ} \mathrm{W}$ ) and one zonal section between $5^{\circ} 40^{\prime} \mathrm{S}$ and $5^{\circ} \mathrm{S}$ (in the following, referred to as $5^{\circ} \mathrm{S}$ ), covering the main part of the DWBC. In November 1992 an additional section was carried out at $10^{\circ} \mathrm{S}$, which extended from the coast to $32^{\circ} 30^{\prime} \mathrm{W}$.

In this study we restrict ourselves to the results found along $35^{\circ} \mathrm{W}, 5^{\circ} \mathrm{S}$, and $10^{\circ} \mathrm{S}$, since the $44^{\circ} \mathrm{W}$ section has much higher temporal coverage in conjunction with other projects and will be analyzed jointly elsewhere. A map of the area with sections and Pegasus station distribution is shown in Figure 1. Mooring-derived mean transports and the temporal variability at $44^{\circ} \mathrm{W}$ are presented by Schott et al. [1993], and the potential of the $\mathrm{F} / \mathrm{l} / \mathrm{F} 12$ ratio in dating and tracking water masses is discussed by Rhein [1994]. Since the topic of the current paper is the deep boundary current, we will only present water masses deeper than about $1200 \mathrm{~m}$. In the following sections the methods used for this study will be outlined first. Next, after defining the boundaries of the water masses in the DWBC, with the help of the CFM and hydrographic data, and comparing them with previous results, the main flow cores of the deepwater masses and their variability are presented. Then, transport estimates from direct velocity measurements and from geostrophic computations are evaluated. The estimates from all three surveys are compared with previous observations and are combined to set up circulation patterns of the deepwater masses.

\section{Methods}

\subsection{CTD Data}

During all three cruises a conductivity-temperature-depth (CTD) model Neil Brown MARK III was used. All sensors (except the pressure sensor) were calibrated in the laboratory before and after the whole expedition, which for the first two cruises lasted almost 1 year and included cruises M14, M15, and MI6. Water samples were collected to calibrate the salinity and oxygen sensors, and protected and unprotected thermometers were mounted on some of the $2410-\mathrm{L}$ Niskin bottles to calibrate pressure and temperature. The temperature accuracy is estimated to be $0.002^{\circ} \mathrm{C}$ for $\mathrm{Ml} 4$, $0.003-0.004^{\circ} \mathrm{C}$ for $\mathrm{Ml}$, and $0.002^{\circ} \mathrm{C}$ for $\mathrm{M} 22$. Because of the pressure dependence of the conductivity cell, the cell was calibrated with bottle sample derived calibration coefficients. The salinity accuracy is of the order of \pm 0.003 for all cruises. The pressure calibration had a standard deviation of \pm 3 dbar compared to the thermometric pressure readings.

\subsection{Oxygen}

Owing to technical problems during the cruise M14, only the oxygen data sampled during M16 in May-June 1991 and during M22 in October-November 1992 are used in this study. The oxygen distribution was an important parameter to define the water masses and their boundaries. The oxygen sensor was calibrated as described by Owens and Millard [1985]. The bottle oxygen samples were analyzed by a modified Winkler titration [Grasshoff et al., 1983] with an accuracy of $\pm 0.06 \mathrm{~mL} \mathrm{~L}^{-1}(\mathrm{M} 16)$ and $\pm 0.016 \mathrm{~mL} \mathrm{~L}^{-1}$ (M22). During M22 the titration was done directly in $100-\mathrm{mL}$ glass bottles, therefore errors arising from sample transfer and cleaning procedures were eliminated. The accuracy of the calibrated sensor data is estimated to be of the order of $\pm 0.15 \mathrm{~mL} \mathrm{~L}^{-1}$

\subsection{Chlorofluoromet hanes}

The CFMs were collected using precleaned 10-L Niskin bottles mounted on a CTD unit. They were analyzed on the ship using a gas chromatographic technique similar to that of Bullister and Weiss [1988]. During all cruises only water masses below $700 \mathrm{~m}$ were sampled. In May-June 1991 the horizontal coverage was only half of that in October 1990 , resulting in a coarser resolution.

The accuracy of seawater CFM concentrations (F11, F12 of $\pm 0.005 \mathrm{pmol} \mathrm{kg}^{-1}$ ) was checked by closing two or more bottles at one depth. In October 1990 and November 1992 the CFM blanks (0.003-0.009 pmol kg $\left.{ }^{-1}\right)$ were checked by analyzing water made CFM free by purging CFM-clean gas through a 10-L glass bottle. In June 1991, blanks were determined following the method described by Rhein [1991], giving similar mean blanks as during the Ml4 cruise. All CFM data reported have been corrected by these blanks. The absolute calibration was done using a gas standard kindly provided by R. Weiss, Scripps Institution of Oceanography. 


\subsection{Pegasus Profiling System}

The Pegasus profiling system [Spain et al., 1981] is used to obtain vertical profiles of absolute velocity. It is a free-falling instrument that follows the horizontal fow and whose motion is tracked with two acoustic transponders deployed on the ocean foor (together with continuous pressure measurements, this yields absolute three-dimensional positions of the probe). The detailed method and procedures used are described by U. Send et al. (Aspects of acoustic transponder surveys and acoustic navigation, submitted to Journal of Atmospheric and Oceanic Technology, 1994). The number of casts at $35^{\circ} \mathrm{W}$ and $5^{\circ} \mathrm{S}$ was 11 during October 1990, 13 during May-June 1991, and 16 in autumn 1992. The actual accuracy of these data (and of any other direct profiling method) is limited by natural variability from internal waves as discussed by Send [1994]. In that paper the resulting effects and quantitative error estimates are studied. For our region of study the approximate errors range from $4 \mathrm{~cm} \mathrm{~s}^{-1}$ at depth to $10 \mathrm{~cm} \mathrm{~s}^{-1}$ below the thermocline (these values represent 2 standard deviations of the error for a single current component).

Pegasus velocity profiles from all three cruises are available on the $35^{\circ} \mathrm{W}$ and $5^{\circ} \mathrm{S}$ sections. However, the spatial resolution during October 1990 at the $5^{\circ} \mathrm{S}$ section turned out to be too coarse to resolve the horizontal velocity pattern properly. Therefore these data (MI4) have been omitted in the presentations and in estimating the DWBC transport.

\subsection{Lowered Acoustic Doppler Current Profiler}

An ADCP had been mounted on the CTD rosette unit as an alternative method to obtain absolute velocity profiles during a CTD station. A detailed description of the technique and data processing is given by Fischer and Visbeck [1993] It is shown there that the velocity profiles obtained by the LADCP agree well with the Pegasus profiles. LADCP casts are available for the $35^{\circ} \mathrm{W}$ section in May-June 1991 (M16) and in November 1992 (M22). The use of the LADCP for the $5^{\circ} \mathrm{S}$ section was prevented by water leakage in the instrument after completing the $35^{\circ} \mathrm{W}$ section on both cruises. The new broadband ADCP, which was used in November 1992 after the failure of the first instrument, was only capable of obtaining velocity profiles above $1300 \mathrm{~m}$ owing to technical problems and thus could not be used for the direct velocity distribution of the deep ocean at $5^{\circ} \mathrm{S}$. Caused by a significant velocity signal in the chosen reference levels east of the DWBC core along $5^{\circ} \mathrm{S}$ in November 1992, the agreement between direct velocity measurements and geostrophic computations was poor. Thus the LADCP was used to adjust the geostrophic profiles with a velocity offset at the reference level.

\subsection{Transport Estimates From Directly Measured Velocity Profiles}

We apply several methods to obtain the velocity field and the corresponding transports. The first approach uses the velocities measured directly at a given location with the Pegasus system and/or the LADCP. Both systems measure absolute velocity profiles at several locations along a section. To estimate the velocity field on the whole section and corresponding transports, the profiles are interpolated between the stations by objective analysis. In general, the velocity profiles from the LADCP compare quite well with the direct measurements of the Pegasus and from moorings
[Fischer and Visbeck, 1993; Schott et al., 1993]. Therefore, whenever available, the velocity data from both methods were combined in the objective analysis to obtain velocity fields and transports. In studying the transports derived from these direct velocity measurements, one has to take into account several uncertainties as described below.

1. There are significant internal wave induced errors in each single vertical profile measured [Send, 1994] which can still be of the order of $4 \mathrm{~cm} \mathrm{~s}^{-1}$ when averaging vertically over typical water mass layers (this is because of the large vertical wavelength of instantaneous internal wave currents). Since each current profile in a section has errors of this type which are uncorrelated, more profiles per section length will reduce the resulting transport error. For example, consider a region of $700 \mathrm{~m}$ vertical extension (typical for NADW water masses) and a horizontal distance between two casts of $70 \mathrm{~km}$ (worst case present at the $35^{\circ} \mathrm{W}$ section). The error in the velocity profiles of the order of $\pm 4 \mathrm{~cm} \mathrm{~s}^{-1}$ causes an associated uncertainty in the transport for that layer of $\pm 2.8 \mathrm{~Sv}$; if, instead of two casts, one distributes five profiles over the same distance, then the uncertainty is reduced to $\pm 1.6 \mathrm{~Sv}$.

2. The moored current meters located at $44^{\circ} \mathrm{W}$ [Schott et al., 1993] showed temporal variability at 30-day and at 60 -day periods that was as high as the average/typical currents, even in the deep boundary current. Such a time dependence of the transport clearly cannot be resolved by three realizations as measured with our surveys. Therefore assuming that the variability at $44^{\circ} \mathrm{W}$ is comparable to that in our sections, the mean transport calculated here could be severely biased. From our sections we can thus only hope to identify the apparently persistent features of the circulation and give the range of observed transport values for the changing flow regimes.

3. When the section is not sufficiently resolved horizontally, transport integrals from linear interpolation between the profiles can result in serious errors. Note that this results from direct measurements being a point measurement, while, e.g., geostrophic transports from CTD profiles inherently represent the average transport between the stations. The objective analysis employed here cannot correct for underresolved data, of course, but, in a sense, is the "best" one can do. The horizontal/vertical correlation scales and the vertical variance distribution used for this result in contour maps that are qualitatively, not grossly different from linear interpolation. However, in some locations the section seems to be marginally resolved and the transport difference between objective analysis and linear interpolation can be $2-3 \mathrm{~Sv}$.

\subsection{Geostrophic Transport Estimates}

The second approach to obtain transports is by geostrophic computations from CTD stations. This method yields the geostrophic velocity profile perpendicular to the section, relative to the flow at some reference level. Unlike the directly measured point velocities discussed above, this is an integral method already representing an estimate of the average flow between the stations used.

The weakness of this method is that a reference velocity has to be assumed to fix the absolute transports and that the geostrophic method generally breaks down at the equator. Even within some interval away from the equator, the method is sensitive to small density changes. Therefore at 
the $35^{\circ} \mathrm{W}$ section the geostrophic approach was applied only south of $3^{\circ} 09^{\prime} S$.

Typical boundaries used as no-motion reference levels in the tropical Atlantic are the potential temperature of $4.7^{\circ} \mathrm{C}$ [Molinari et al., 1992] or a depth of $1200 \mathrm{~m}$ [Speer and McCartney, 1991]. Another boundary between southeast flow (NADW) and northwest flow is near the potential temperature of $1.8^{\circ} \mathrm{C}$. At $5^{\circ} \mathrm{S}$ the latter is located between $3680 \mathrm{~m}$ near the South American continent and $3900 \mathrm{~m}$ farther offshore. As will be discussed in section 3 , the $1.8^{\circ} \mathrm{C}$ isotherm lies close to the density $\sigma_{4}=45.90$ which separates the LNADW from the AABW. For stations deeper than this isopycnal this was the reference level we chose for our geostrophic transports.

The other boundary between northwestward flow and southeastward flow is the density of $\sigma_{1}=32.15$, which we selected as the upper boundary of the NADW (see section $3)$. This density surface is located in depths between 1000 and $1200 \mathrm{~m}$ and is used in our calculations as a reference depth for the stations shallower than the deep reference level of $\sigma_{4}=45.90$. In general, the choice of the two density surfaces as a level of no motion for the geostrophic computations agrees with the directly measured velocity field, although the Pegasus zero-velocity depths tend to be slightly shallower.

In comparing the transports derived from geostrophy and direct measurements, one has to take into account that an uncertainty in the barotropic velocity of $\pm 2 \mathrm{~cm} \mathrm{~s}^{-1}$ at the level of no motion causes a transport error of typically \pm 1.4 Sv (assuming vertical extension of $700 \mathrm{~m}$ and a horizontal extension of $100 \mathrm{~km}$ ). In summary, the presented transport calculations are subject to considerable uncertainties caused by the errors of the methods. Even if the transport estimates from the three cruises agree well, the number obtained may not represent the annual mean transport owing to a possible bias by the temporal variability present in the velocity field.

\section{Water Masses}

In the following the distribution of the water masses as observed during the "Meteor" cruises in October 1990, May-June 1991, and October-November 1992 are presented (Figures 2-5), discussed and compared to existing literature. Furthermore, a synopsis of previous results and our hydrographic and tracer data serves to define density boundaries of the various water masses present in our data. These density boundaries will later be used for comparison of the water mass distributions with the flow structures and for estimating transports of the various components. The limits and characteristics of the water masses that will be discussed in the following are summarized in Table 1.

\subsection{Shallow Upper NADW}

The CFM and tritium data, which have been used recently in the tropical and subtropical Atlantic to trace deepwater masses of northern origin [Fine and Molinari, 1988; Rhein, 1994], indicate an additional, separate water mass within the upper NADW. The tracer maximum [Weiss et al., 1985] can be seen as a very conspicuous feature around $1600-1700 \mathrm{~m}$ depth in all our CFM sections (Figures 3 and 4). This constitutes the shallowest part of the NADW [Weiss et al., 1985; Fine and Molinari, 1988; Molinari et al., 1992] and is hereinafter referred to as the "shallow upper NADW"
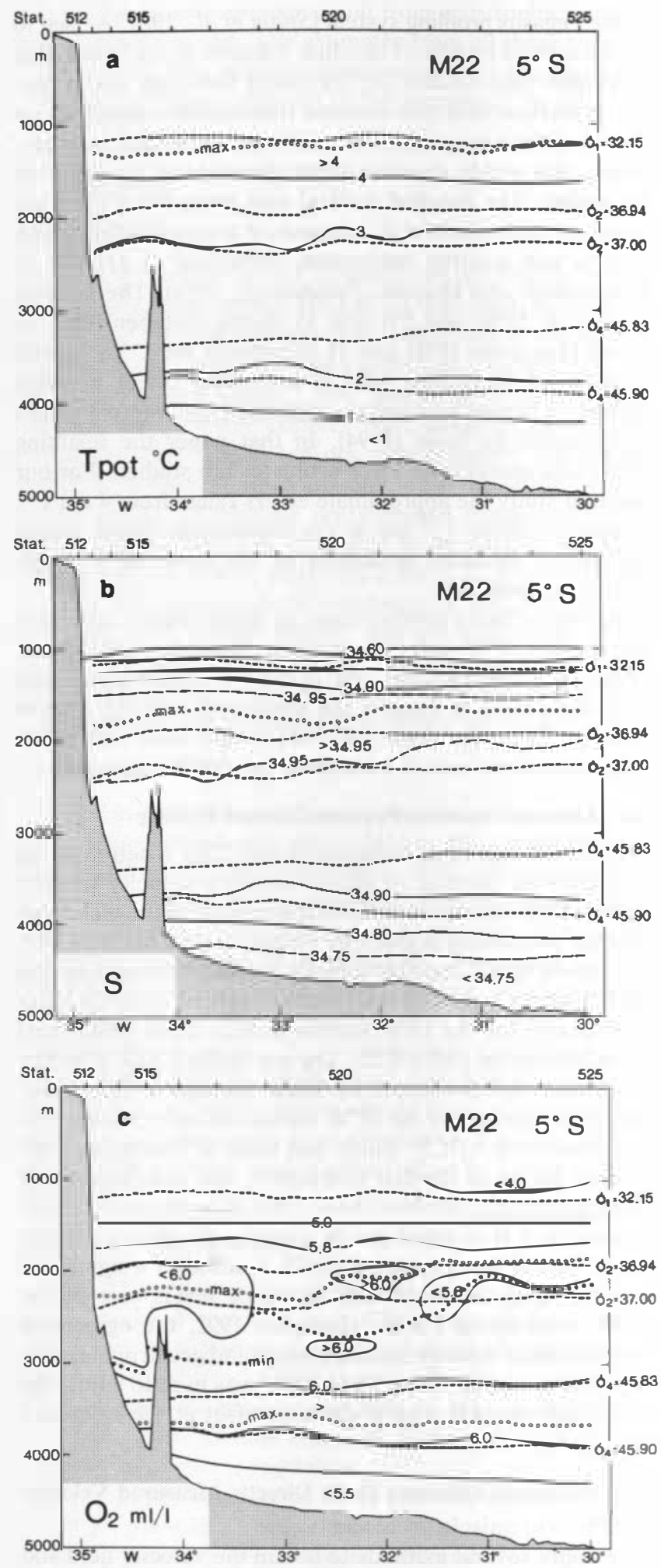

Figure 2. Distributions below $1000 \mathrm{~m}$ depth along $5^{\circ} \mathrm{S}$, November 1992 (M22) of (a) potential temperature in degrees Celsius, (b) salinity, and (c) dissolved oxygen in milliliters per liter. Relative maxima are denoted by open circles and minima (Figure 2c) by solid circles. Also shown are the isopycnals (short-dashed lines) defining the water mass boundaries. In Figure $2 \mathrm{~b}$ the isohalines $\mathbf{3 4 . 7 5}$ and 34.95 are plotted as well (long-dashed lines). 

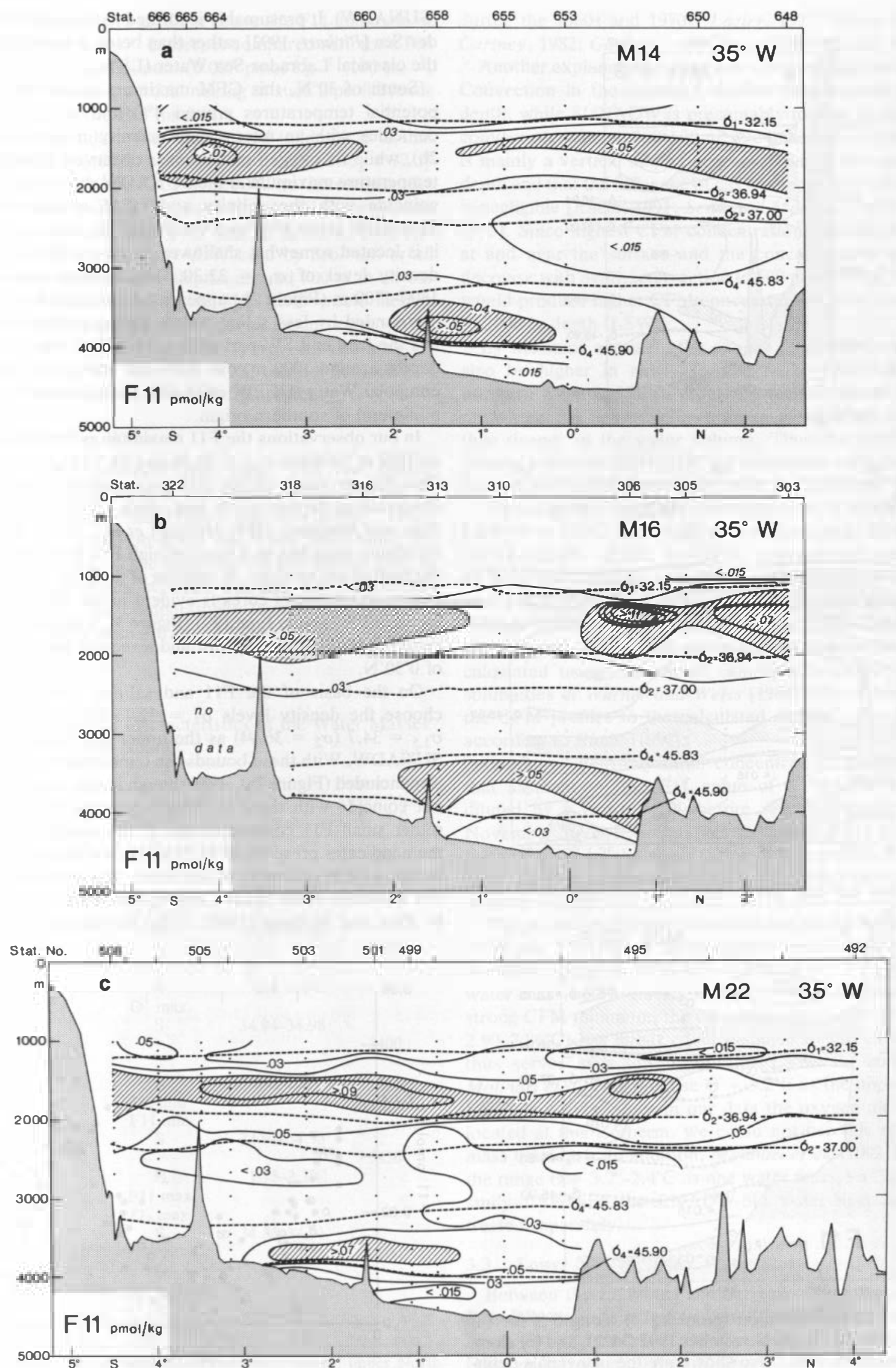

Figure 3. Chlorofluoromethane F11 distribution (pmol kg ${ }^{-1}$ ) along $35^{\circ} \mathrm{W}$ for (a) October 1990 (M14), (b) May-June 1991 (M16), and (c) November 1992 (M22). Also shown are the isopycnals defining the water mass boundaries (dashed lines). The maxima of the shallow upper north Atlantic Deepwater (SUNADW) and overflow lower NADW (OLNADW) are stippled. 

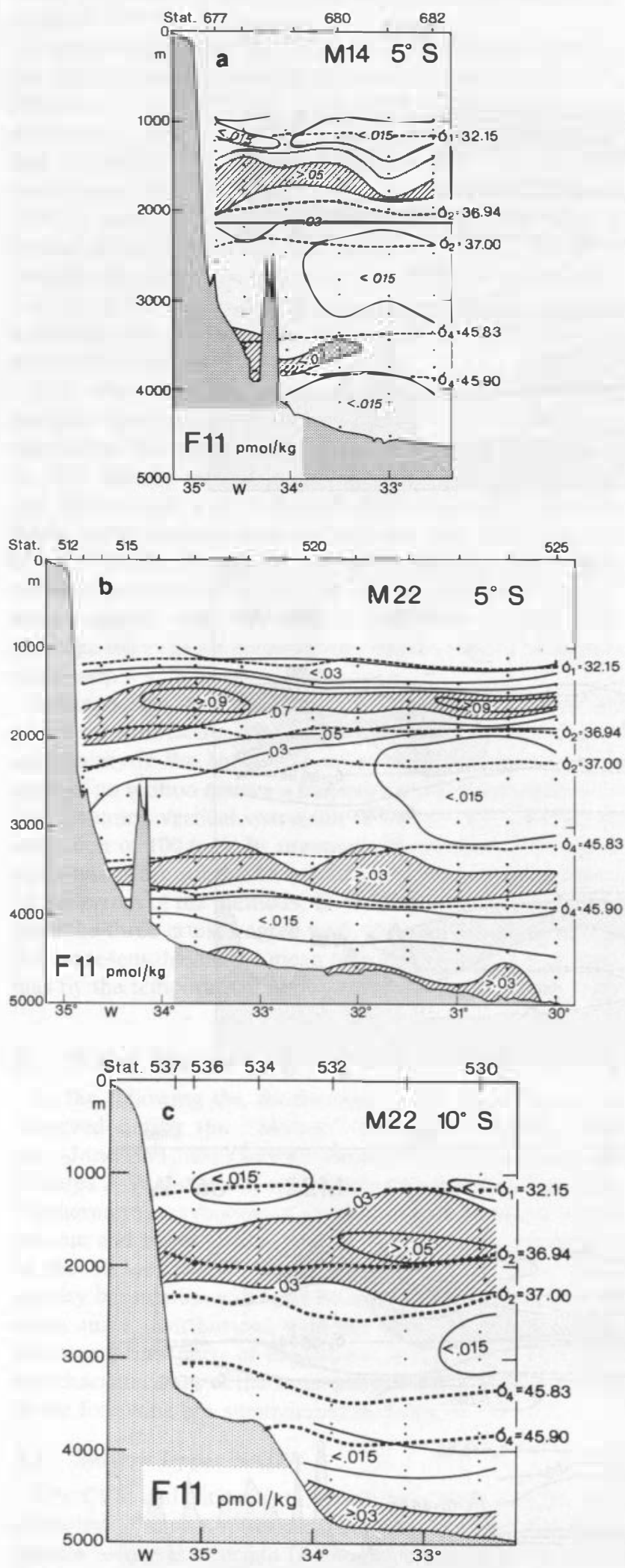

Figure 4. Fll distribution (pmol $\mathrm{kg}^{-1}$ ) along $5^{\circ} \mathrm{S}$ for (a) October 1990 (M14), (b) November 1992 (M22), and (c) along $10^{\circ} \mathrm{S}$, November 1992. Also shown are the isopycnals defining the water mass boundaries. The maxima of the SUNADW and OLNADW, (at $10^{\circ} \mathrm{S}$, the Antarctic Bottom Water (AABW)) are stippled.
(SUNADW). It presumably is formed in the southem Labrador Sea [Pickart, 1992] rather than being a modified form of the classical Labrador Sea Water (LSW).

South of $30^{\circ} \mathrm{N}$, this CFM maximum is usually found at potential temperatures around $4^{\circ} \mathrm{C}$ and $\sigma_{1.5}=34.63$. It coincides with an intermediate salinity maximum (Figure $2 b$ ), while no oxygen maximum is observed (Table 1). The temperature maximum in the SUNADW, however, does not coincide with the salinity and CFM maximum of the SUNADW at the $35^{\circ} \mathrm{W}$ and $5^{\circ} \mathrm{S}$ (Figure $2 \mathrm{~b}$ ) sections. Instead, it is located somewhat shallower, around $1100-1300 \mathrm{~m}$ at a density level of $\sigma_{1}=32.20$. The salinity maximum at $1600-1700 \mathrm{~m}$ (Figure 2b) appears because the SUNADW is surrounded by less saline waters above and below; below lies the fresher LSW part of the UNADW, while above, in depths around $1000 \mathrm{~m}$, one finds the low-saline upper Circumpolar Water (UCPW) (also with a temperature and CFM minimum) of southern origin.

In our observations the F11 maximum is centered at 1600 $\mathrm{m}-1800 \mathrm{~m}$ between $\sigma_{1.5}=34.56$ and 34.7 (Figures 3 and 4). This density range of the Fll maximum is similar to the observations farther north and south [Weiss et al., 1985; Fine and Molinari, 1988; Molinari et al., 1992]. The tracer maximum stretches as a band of high Fll from the coast to the limit of our sections. A splitting of the high-F11 band into two main maximum cores is evident in the data at $35^{\circ} \mathrm{W}$ in October 1990 and in June 1991 (Figure 3), with one maximum centered south of the equator and a second maximum north of $0^{\circ} 30^{\prime} \mathrm{N}$.

On the basis of the FII and salinity distributions we choose the density levels $\sigma_{1}=32.15\left(\sigma_{1.5}=34.42\right)$ and $\sigma_{1.5}=34.7\left(\sigma_{2}=36.94\right)$ as the upper and lower limits for SUNADW. With these bounds the temperature maximum is also included (Figure 2a), even though in our sections it does not coincide with the FI1 salinity maximum and exhibits rather small Fll concentrations. If the temperature maximum indicates presence of SUNADW, we would not expect to find a CFM minimum at this level. The truncation of the F11 minimum of the upper Circumpolar Water, as described by Fine and Molinari [1988], could be responsible for that

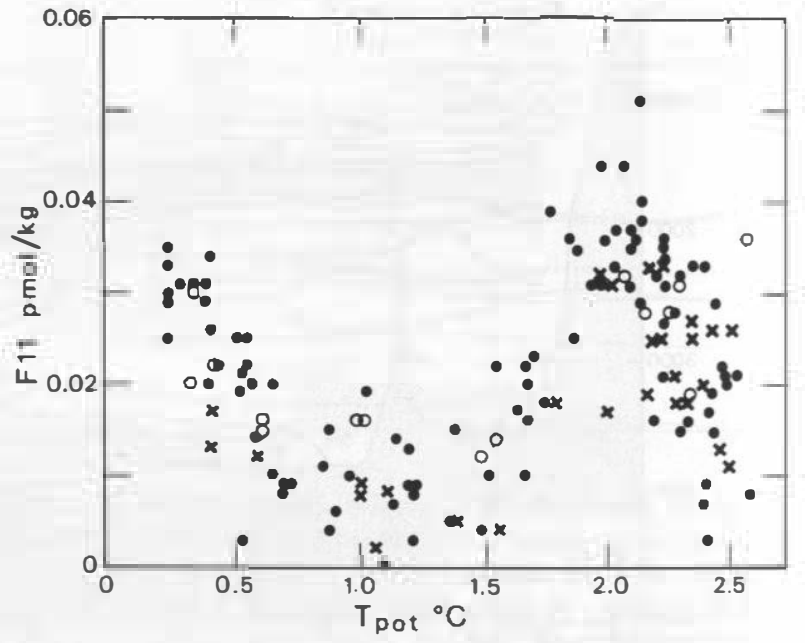

Figure 5. F 11 concentrations $\left(\mathrm{pmol} \mathrm{kg}^{-1}\right.$ ) versus potential temperature $\Theta$ for the lower NADW at the $5^{\circ} \mathrm{S}$ section, October 1990 (crosses), June 1991 (open circles), and November 1992 (solid circles). 
feature; the vertical F11 gradient above the F11 minimum of $0.05 \mathrm{pmol} \mathrm{kg}^{-1}(100 \mathrm{~m})^{-1}$ is steeper compared with the CFM gradient below the minimum $\left(0.007 \mathrm{pmol} \mathrm{kg}^{-1}(100 \mathrm{~m})^{-1}\right.$, Figure 3). Subsequent vertical mixing of such a profile leads to a deepening of the FI1 minimum.

The upper boundary thus determined is identical to that used by Stramma [1991], who used the density of $\sigma_{1}=32.15$ as a boundary for the UCPW/NADW to investigate the geostrophic transports of the South Equatorial Current in the Atlantic. By contrast, the upper limit of potential temperature $\Theta=4.7^{\circ} \mathrm{C}$ for the SUNADW used by Molinari et al. [1992] would correspond to depths around $700 \mathrm{~m}$ in all our sections. With that boundary the SUNADW would include the total depth range of the CFM minimum zone of the UCPW as well as part of the above lying Antarctic Intermediate Water (AAIW). Thus $\Theta=4.7^{\circ} \mathrm{C}$ can not be used as a water mass boundary in the equatorial region.

\subsection{Labrador Sea Water}

In the central Labrador Sea, water with low density gradients and high oxygen concentrations is formed by deep-reaching convection [Talley and McCartney, 1982]. Molinari et al. [1992] observed this water mass along the Brazilian continent, in the northwest of our survey area, at potential temperatures between 3.2 and $3.6^{\circ} \mathrm{C}$ in depths around $2000 \mathrm{~m}$. The comparatively low CFM and tritium load of LSW have been attributed to incomplete convection

Table 1. Limits and Characteristics of the Water Masses in the Deep Western Atlantic

\begin{tabular}{|c|c|c|c|}
\hline $\begin{array}{l}\text { Water Mass or } \\
\text { Density Boundary }\end{array}$ & Property & Range & $\begin{array}{c}\text { Approximate } \\
\text { Depth Mean } \\
35^{\circ} \mathrm{W}, 5^{\circ} \mathrm{S}, \mathrm{m}\end{array}$ \\
\hline $\begin{array}{c}\sigma_{1}=32.15 \\
\sigma_{1.5}=34.42\end{array}$ & & & 1200 \\
\hline & $\Theta \max$ & $3.4-4.5^{\circ} \mathrm{C}$ & \\
\hline SUNADW & $\begin{array}{l}\text { F1l max } \\
\mathrm{S} \text { max }\end{array}$ & $34.80-35.00$ & \\
\hline $\begin{array}{c}\sigma_{2}=36.94 \\
\sigma_{1.5}=34.70\end{array}$ & & & 1900 \\
\hline & $\Theta$ & $2.8-3.4^{\circ} \mathrm{C}$ & \\
\hline LSW & $\mathrm{O}_{2} \max$ & $34.94-34.98$ & \\
\hline $\begin{aligned} \sigma_{2} & =37.00 \\
\sigma_{15} & =34.755\end{aligned}$ & & & 2400 \\
\hline & $\Theta$ & $2.2-2.8^{\circ} \mathrm{C}$ & \\
\hline LNADW-old & $\begin{array}{l}\mathrm{O}_{2} \text { min } \\
\mathrm{F} 11 \text { min } \\
\mathrm{S}\end{array}$ & $34.91-34.95$ & \\
\hline$\sigma_{4}=45.83$ & $\Theta$ & $1.75-2.2^{\circ} \mathrm{C}$ & 3450 \\
\hline OLNADW & $\begin{array}{l}\mathrm{F} 11 \text { max } \\
\mathrm{O}_{2} \text { max } \\
\mathrm{S}\end{array}$ & $34.85-34.91$ & \\
\hline$\sigma_{4}=45.90$ & $\theta$ & $<1.75^{\circ} \mathrm{C}$ & 3900 \\
\hline AABW & $\begin{array}{c}\text { decrease in } \mathrm{S}, \mathrm{O}_{2}, \mathrm{~T} \\
\mathrm{~S} \\
\text { F11 increase }\end{array}$ & $<34.85$ & \\
\hline
\end{tabular}

Abbreviations are $\sigma$, density; SUNADW, shallow, upper North Atlantic Deep Water; $\Theta$, potential temperature; max, maximum; Fl 1, chlorofluoromethane; S, salinity; LSW, Labrador Sea Water; LNADW-old, lower NADW old water mass; min, minimum; OLNADW, overfow lower NADW; AABW, Antarctic Bottom Water; $\mathrm{T}$, temperature. during the 1960s and 1970s [Lazier, 1973; Talley and McCartney, 1982; Gascard and Clarke, 1983; Lazier, 1988].

Another explanation for the low CFM could be as follows. Convection in the central Labrador Sea exceeds $2000 \mathrm{~m}$ depth, while SUNADW is presumably formed by shallower convection down to $500-600 \mathrm{~m}$. We believe that convection is mainly a vertical mixing process down to the convection depth and that the influence of gas exchange and entrainment is negligible [Rhein, 1991; Send and Marshall, 1994; Rhein, 1995]. Since highest CFM concentrations are usually found at and near the surface and the concentrations generally decrease with depth, convection to $500 \mathrm{~m}$ depth (SUNADW) would produce higher CFM concentrations than convection to $2000 \mathrm{~m}$ depth (LSW).

By the same argument the oxygen concentrations should also be higher in newly formed SUNADW, but in the northem Atlantic this water mass is located around 600-700 $\mathrm{m}$, where the oxygen consumption is significantly higher than deeper in the water column. Thus the initially high oxygen values of SUNADW are consumed while the newly formed SUNADW flows away from the Labrador Sea.

We calculated the CFM concentrations in newly formed LSW $\left(\Theta=3.5^{\circ} \mathrm{C} ; \mathrm{S}=34.88\right.$; convection depth, $\left.2000 \mathrm{~m}\right)$ and SUNADW $\left(\Theta=4.5^{\circ} \mathrm{C} ; \mathrm{S}=34.80\right.$; convection depth, $\left.500 \mathrm{~m}\right)$ by using the following assumption from Rhein [1991]: during convection only homogenization of the convected water column occurs but no additional gas exchange with the atmosphere. The annual surface CFM concentrations are calculated using the known atmospheric values and the solubilities of Warner and Weiss [1985]. The adjustment of the CFM profiles to the calculated surface values is done according to Rhein [1991].

Compared with the initial concentrations resulting from that assumption, the FIl value of SUNADW has been diluted by a factor of 29 before reaching the equator in November 1992. If one dilutes the initial CFM concentrations of LSW by the same factor, a concentration of 0.065 pmol $\mathbf{k g}^{-1}$ is obtained similar to the observations in the tropical Atlantic.

The oxygen maximum characterizing the LSW is found at $35^{\circ} \mathrm{W}$ and $5^{\circ} \mathrm{S}$ (Figure 2c) in depths around $2100 \mathrm{~m}$ and at densities around $o_{2}=36.965-36.970\left(\Theta=3.2^{\circ} \mathrm{C}\right)$. Since the water mass below carries a slight oxygen minimum and a strong CFM minimum, the density surface $\sigma_{2}=37.00(\Theta=$ $2.90-2.86^{\circ} \mathrm{C}$ ) has about equal distance to the extrema and thus serves as a lower limit for LSW. By comparison, Molinari et al. [1992] chose $\Theta=3.2^{\circ} \mathrm{C}$ as the upper limit of LSW. However, since in our data the oxygen maximum is located at this isotherm, we could not use this as a water mass boundary. In addition, Molinari et al. [1992] regarded the range $\Theta=3.2^{\circ}-2.4^{\circ} \mathrm{C}$ as one water mass, so that in their study LSW and the LNADW-old water mass were not treated separately.

\subsection{Lower NADW "Old" Water Mass}

Between the LSW and the deep tracer maximum of the LNADW there is a low-oxygen, low-FIl layer found between $\Theta=3.2$ and $2.4^{\circ} \mathrm{C}$ to the north of our study region [Fine and Molinari, 1988; Molinari et al., 1992]. Owing to the $\Theta-S$ characteristic of the source water masses of NADW, water in this temperature range presumably consists of mainly Gibbs Fracture Zone Water (GFZW), which compared to the surrounding water masses leaves the formation 
region with relatively low $\mathrm{F} 11$ and tritium concentrations [Smethie and Swifit, 1989; Rhein, 1994]. Furthermore, the associated velocities tend to be smaller than in the zones with a tracer maximum [e.g., Fine and Molinari, 1988; Watts, 1990; Schott et al., 1993; Richardson and Schmitz, 1993], causing the CFM signal of the two water masses to differ even more.

At $35^{\circ} \mathrm{W}$ and $5^{\circ} \mathrm{S}$ the Fl 1 minimum (concentrations $<0.015$ pmol $\mathrm{kg}^{-1}$ ) lies between 2400 and $3100 \mathrm{~m}$, a range that includes the oxygen minimum found at $2700 \mathrm{~m}$ depth and densities around $\sigma_{2}=37.03$. The near-shore FII concentrations are higher but do not exceed $0.027 \mathrm{pmol} \mathrm{kg}^{-1}$ (Ml4, M16) and $0.038 \mathrm{pmol} \mathrm{kg}^{-1}$ (M22). The offshore decrease could be caused by contributions of "older" water recirculating and/or, as Reid [1990] suggests, could be water of southern hemispheric origin.

The near-shore CFM concentration differences between LNADW-old and OLNADW can be explained entirely by their different boundary conditions and formations. Specifically, the main contributor to LNADW-old, the GFZW, starts in its formation region with only $40 \%$ of the FI 1 concentrations of the neighboring OLNADW (see section 3.4). The LNADW-old is limited by $\sigma_{2}=37.00$ and $\sigma_{4}=$ 45.83 .

\subsection{Lower NADW Overflow Water}

The deepest part of the NADW, centered around $\Theta=2^{\circ} \mathrm{C}$ in the subtropical and tropical Atlantic, exhibits a distinct tracer and oxygen maximum [Fine and Molinari, 1988; Speer and McCartney, 1991; Molinari et al., 1992]. Both maxima reflect the convective renewal of one of the northern source water masses (Denmark Strait Overflow Water (DSOW), e.g., Smethie and Swift [1989]; Rhein [1994]). The oxygen and silica signal of this water mass can be followed along the western boundary to $5^{\circ} \mathrm{S}$ [Speer and McCartney, 1991].

The continuation of the Fll rich water mass across the equator to $5^{\circ} \mathrm{S}$ is obvious from the M14 and M22 data (Figure $4)$, despite the decreasing Fll signal and changing $\Theta-S$ characteristics. Both the CFM and oxygen distributions point to $\sigma_{4}=45.83$ as an upper boundary. For the lower boundary one could choose a density level of $\sigma_{4}=45.92$ as did Roemmich [1983] and Schlitzer [1988], which would be compatible with the F11 distributions at $44^{\circ} \mathrm{W}$ and $35^{\circ} \mathrm{W}$. However, at $5^{\circ} \mathrm{S}$ the FII and temperature data $\left(\Theta<1.5^{\circ} \mathrm{C}\right)$ do not support this choice. Thus for our sections a density boundary of $\sigma_{4}=45.90$ (corresponding to temperatures $>1.75^{\circ} \mathrm{C}$ ) seems more appropriate.

\subsection{Antarctic Bottom Water}

Below the generally southward flowing deepwaters of northern origin there are decreasing salinities and oxygen values as well as temperatures below $1.75^{\circ} \mathrm{C}$, indicating the presence of Antarctic Bottom Water (AABW). The name $A A B W$ is somewhat misleading, as most of this water mass originates from the circumpolar water masses, and only its densest part ( $\sigma_{4}>46.06$; Reid [1989]) is renewed in the Weddell Sea. Weddell Sea Deep Water (WSDW) exhibits relatively high CFM concentrations [Bullister, 1989], whereas the circumpolar layers carry old deepwater masses with minor or negligible tracer content.

In October 1990 and May-June 1991 the Fl 1 concentrations of $\mathrm{AABW}$ at $35^{\circ} \mathrm{W}$ and $5^{\circ} \mathrm{S}$ are near the detection limit. Despite these low concentrations the data of 1990 and 1991 at $5^{\circ} \mathrm{S}$ show a slight F11 increase with depth for densities $\sigma_{4}>45.94$ and $\Theta<1.2^{\circ}$ (Figure 5), with even higher values in June 1991. This increase in AABW could indicate the advent of the CFM signal of WSDW, although in an indirect way, in that the highest densities found at $5^{\circ} S\left(\sigma_{4}=46.02\right)$ belong to the tracer poor Circumpolar Water. Thus the FI 1 increase with depth in AABW has to be the result of vertical mixing between Circumpolar Water and denser, colder, CFM rich WSDW in the South Atlantic. The feature was not present at $35^{\circ} \mathrm{W}$, where Fll concentrations $<0.015$ pmol $\mathrm{kg}^{-1}$ characterize the AABW in those years. The observations in November 1992, especially at $5^{\circ} \mathrm{S}$ and $10^{\circ} \mathrm{S}$, con firmed this feature (Figure 5). During that time the signal was also seen at $35^{\circ} \mathrm{W}$. Unfortunately, no reliable FI2 data exist south of the equator, so that an FII/FI2 ratio-derived age cannot be calculated.

\section{Velocity Fields and Transports of the Deep Water Masses}

In this section we present the flow distribution of the various deepwater masses described above, discussing, in particular, the location of the main transport cores and the features persistent in all our surveys. The discussion concentrates on the $35^{\circ} \mathrm{W}$ and the $5^{\circ} \mathrm{S}$ sections, because the section at $10^{\circ} \mathrm{S}$ was only occupied once and extended only to $32^{\circ} 30^{\prime} \mathrm{W}$. The combined (Pegasus and LADCP) flow across the sections is presented in Figures 6 and 7. Also included are the isopycnals which have been chosen as water mass boundaries. For comparison the velocity patterns from geostrophic computations at $5^{\circ} \mathrm{S}$ are shown in Figure 8.

In this section we also present and discuss the transport estimates for the deep boundary current regime, from all three cruises and from both measurement methods (direct, i.e., Pegasus, LADCP, and geostrophic). Figures 9 and 10 show the flow features that are persistent in our three realizations, together with the isopycnals defining the water mass boundaries and the mean transports of these features. The transports have been averaged using the estimates from all cruises and both methods (where data were reliable and station resolution sufficient). The quoted standard deviations indicate the variability about the mean. Note that with only three realizations we cannot hope to produce values with reliable "statistics." Rather, the values have to be taken as an indication of the typical conditions or the variability. However, we believe these are relevant and useful results, especially in comparison with many previous estimates for the deep boundary current transport based on one sample where questions about variability never arise. A significant conclusion from our work will not only be estimates of the DWBC transport crossing the equator but the presence and character of the variability itself. The individual estimates are given in the appendix.

If not noted otherwise, the means and standard deviations in the following sections are calculated from the transport estimates of the direct velocity fields and from geostrophic computations, using $\sigma_{4}=45.90$ as a reference level, or if the station is not deep enough, $\sigma_{1}=32.15$ was selected as the level of no motion. The geostrophic computations are omitted from the transport calculations at the $35^{\circ} \mathrm{W}$ section north of $3^{\circ} 09^{\prime} \mathrm{S}$ (too close to the equator). The transports derived from the Pegasus data for the $5^{\circ} \mathrm{S}$ section in October 1990 and the $35^{\circ} \mathrm{W}$ section south of $3^{\circ} 09^{\prime} \mathrm{S}$ (October 1990 and June 

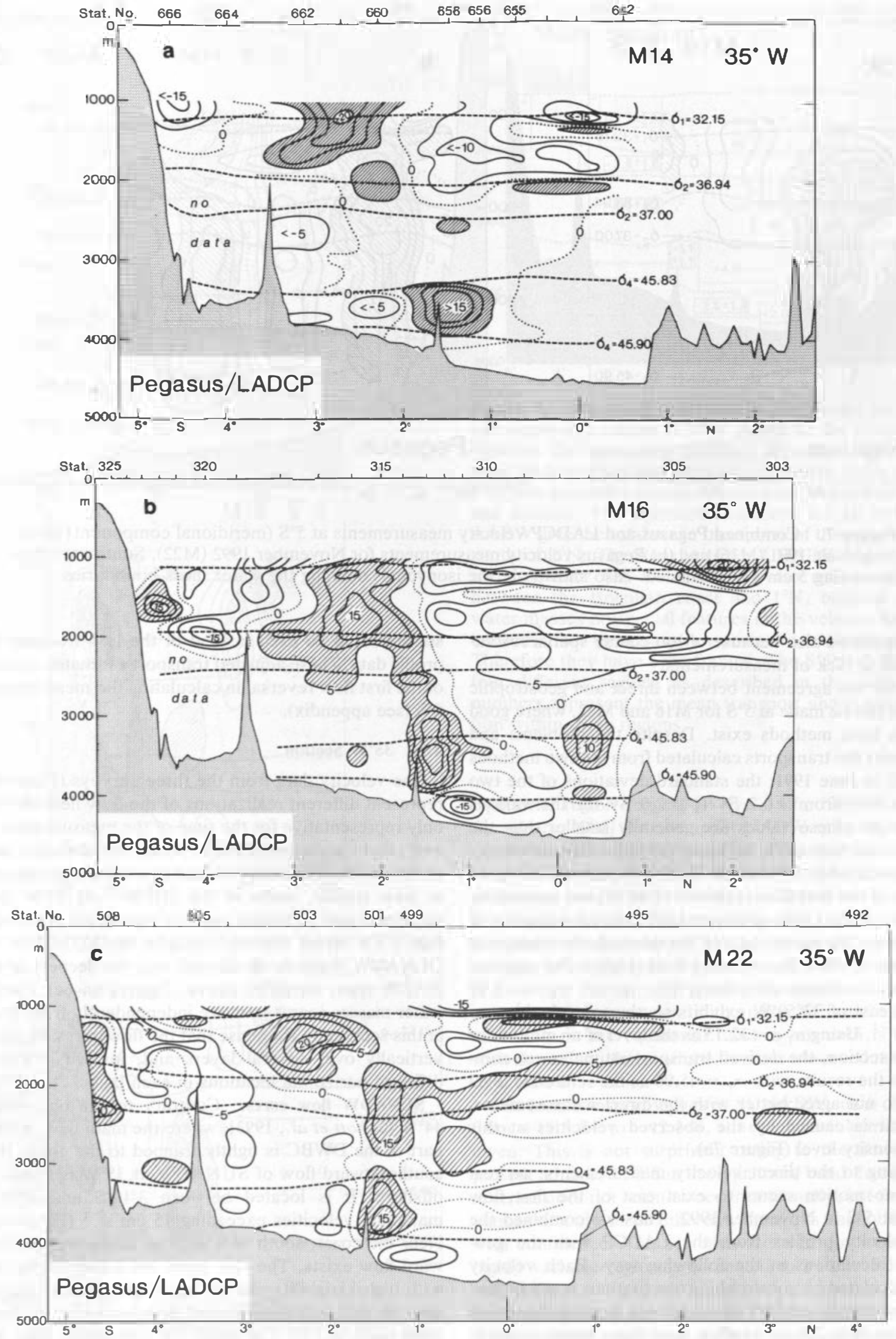

Figure 6. Combined Pegasus and LADCP velocity fields below $1000 \mathrm{~m}$ at $35^{\circ} \mathrm{W}$ (zonal component) for (a) October 1990 (M14), (b) May-June 1991 (M16), and (c) November 1992 (M22). Also shown are the station locations and the isopycnals defining the water mass boundaries. Eastward flow exceeding $5 \mathrm{~cm} \mathrm{~s}^{-1}$ is shaded. 

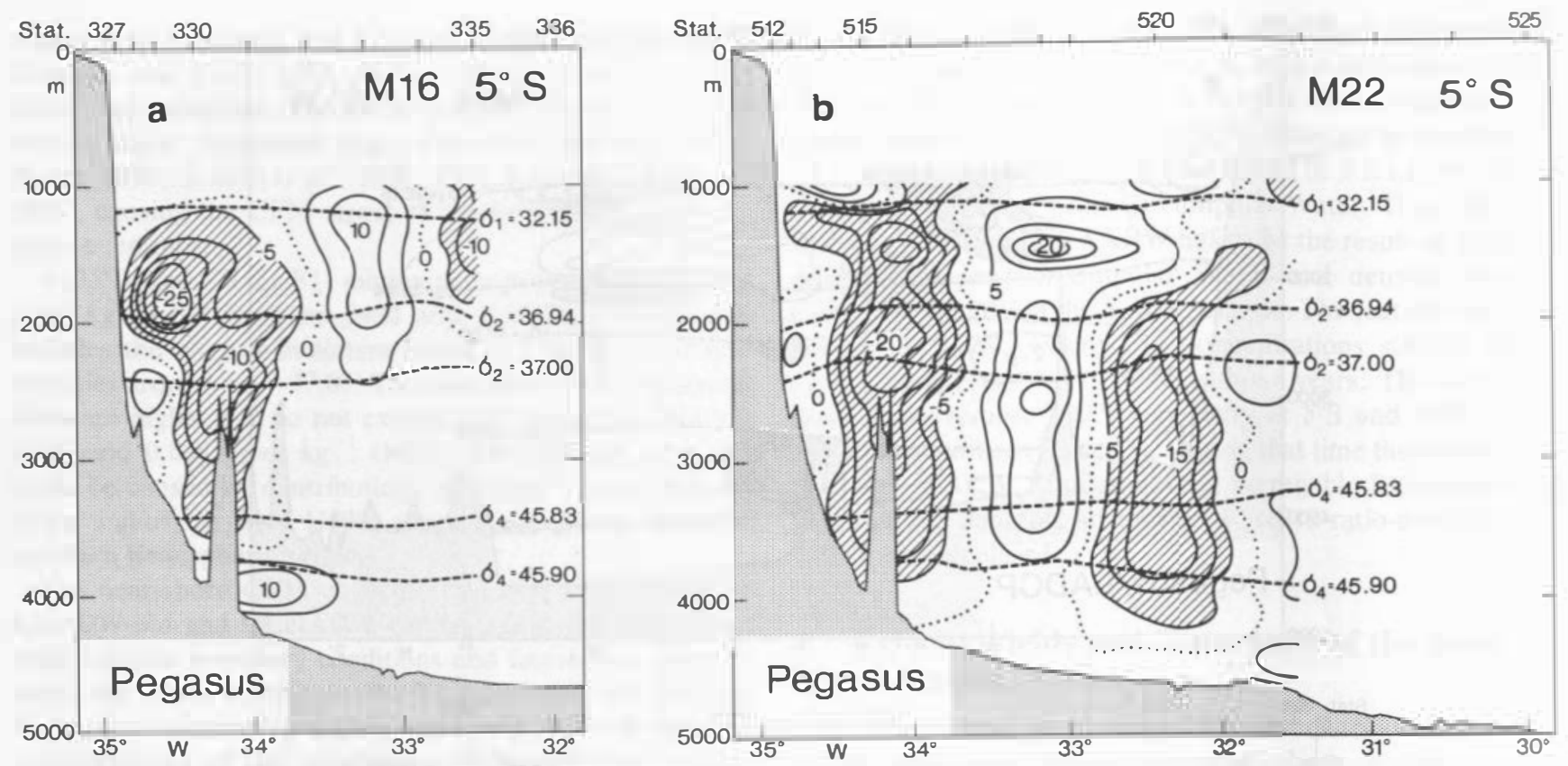

Figure 7. Combined Pegasus and LADCP velocity measurements at $5^{\circ} \mathrm{S}$ (meridional component) for (a) May-June 1991 (M16) and (b) Pegasus velocity measurements for November 1992 (M22). Southward flow exceeding $5 \mathrm{~cm} \mathrm{~s}^{-1}$ is shaded. Also shown are the isopycnals defining the water mass boundaries.

1991) are omitted also because of too coarse spatial resolution or due to lack of measurements.

A test for the agreement between direct and geostrophic transports can be made at $5^{\circ} \mathrm{S}$ for M16 and M22, where good data from both methods exist. Despite the problems and uncertainties the transports calculated from the two methods agree well in June 1991; the standard deviations of the two estimates vary from $\pm 0.2 \mathrm{~Sv}$ to $\pm 2.0 \mathrm{~Sv}$ for the various water masses (these values are generally smaller than the changes in the transports between the individual surveys).

The transports at $5^{\circ} \mathrm{S}$ estimated for November 1992 agree well west of the first flow reversal $\left(33^{\circ} 40^{\prime} \mathrm{W}\right.$, see appendix), although the direct measurements lead to larger values in all water masses. However, east of the reversal, the transports differ considerably. The velocity field (Figure $7 \mathrm{~b}$ ) suggests the reason for these deviations; that is, the $\sigma_{4}=45.90$ isopycnal east of $32^{\circ} 50^{\prime} \mathrm{W}$ exhibits southward velocities up to $15 \mathrm{~cm} \mathrm{~s}^{-1}$. Using $\sigma_{1.5}=32.15$ as the level of no motion for the entire section, the derived transport estimates are comparable to the results with $\sigma_{4}=45.90$ as the reference level and yet do not agree better with the direct measurements. This result is caused by the observed velocities at this shallow density level (Figure 7b).

According to the direct velocity measurements, no real level of no motion seems to exist east of the first flow reversal at $5^{\circ} \mathrm{S}$ in November 1992. Thus we combined the direct velocity profiles from the LADCP with the geostrophic calculations in the following way. Each velocity profile calculated by geostrophic computations was adjusted by an appropriate velocity off set derived from the observed velocity profiles. These profiles have been interpolated to the horizontal location of the geostrophic profile. The offset was calculated by averaging the velocity profiles of the LADCP measurements between $150 \mathrm{~m}$ and $1000 \mathrm{~m}$ depth. This depth interval is located below the Ekman layer and yet shallow enough so that the LADCP data taken on every CTD station could be used instead of the less frequent Pegasus profile data. These adjusted transport estimates are used east of the first flow reversal in calculating the mean transports at $5^{\circ} \mathrm{S}$ (see appendix).

\section{1. $35^{\circ} \mathrm{W}$ Section}

The velocity data from the three surveys (Figures $6 a-6 c$ ) represent different realizations of the flow field and thus are only representative for the time of the measurements. However, there are some features which are common in all our observations and thus presumably can indicate the mean, or at least typical, paths of the DWBC. At $35^{\circ} \mathrm{W}$ the most prominent and persistent velocity signals are observed in the high CFM layers corresponding to the SUNADW and the OLNADW, i.e., the shallowest and the deepest of the four NADW types identified above (Figures $6 a-6 c$ ). Each of the water masses seems to move independently from the others at this section, in the sense that the flow cores do not extend vertically over several layers and, instead, are found at different horizontal locations in each layer.

SUNADW flow cores. Contrary to the observations at $44^{\circ} \mathrm{W}$ [Schott et al., 1993], where the main flow of the upper part of the DWBC is tightly trapped to the coast, the main southeastward flow of SUNADW at $35^{\circ} \mathrm{W}$ is found $320 \mathrm{~km}$ offshore. It is located between $3^{\circ} 10^{\prime} \mathrm{S}$ and $1^{\circ} 50^{\prime} \mathrm{S}$ with maximum velocities exceeding $15 \mathrm{~cm} \mathrm{~s}^{-1}$ (Figures 6a-6c). Near the coast, south of $4^{\circ} 30^{\prime} \mathrm{S}$ an additional smaller eastward flow exists. The two cores are separated by a region with high variability and no persistent velocity signal (Figures $6 \mathrm{~b}$ and $6 \mathrm{c}$ ). A westward flow occurred in this water mass north of $1^{\circ} 50^{\prime} \mathrm{S}$ to about $1^{\circ} \mathrm{N}$ (velocity $v>10 \mathrm{~cm} \mathrm{~s}^{-1}$ ) in October 1990 and was most pronounced in May-June 1991. In November 1992 the flow north of $1^{\circ} 50^{\prime} \mathrm{S}$ was eastward, except for a small region near $1500 \mathrm{~m}$ depth, and extended farther north than in the previous cruises.

The salinity and tracer tongues spreading east in the 

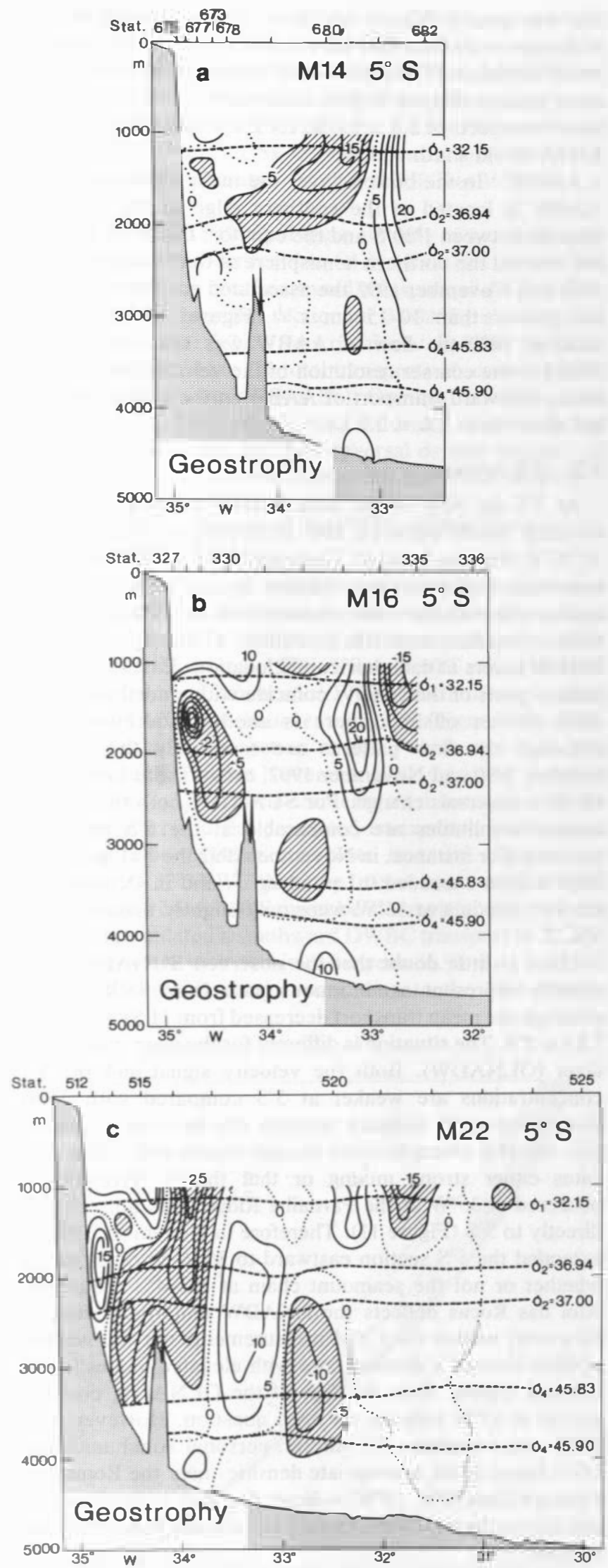

Figure 8. Velocity field at the $5^{\circ} \mathrm{S}$ section from geostrophic computations with a reference density $\sigma_{1}=32.15$ near the coast and $\sigma_{4}=45.90$ in the deep ocean for (a) October 1990 (M14), (b) June 1991 (M16), and (c) November 1992 (M22). Southward flow exceeding $5 \mathrm{~cm} \mathrm{~s}^{-1}$ is shaded. Also shown are the isopycnals defining the water mass boundaries.

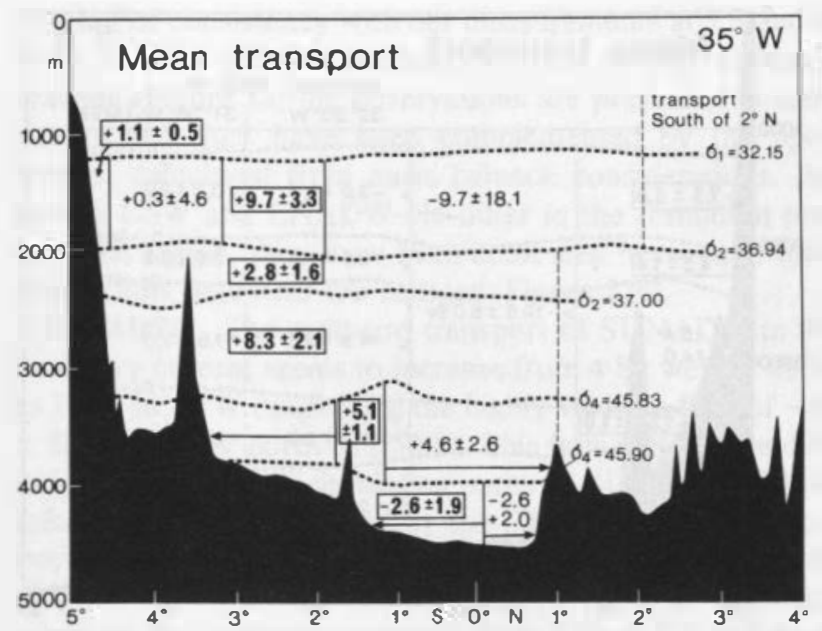

Figure 9. Transport estimates (in sverdrups) for the various deepwater masses at $35^{\circ} \mathrm{W}$ shown for the discussed flow regimes. The mean and standard deviations are calculated from the individual computations presented in the appendix. Features which are relatively persistent, are in bold numbers and framed. The rightmost numbers for OLNADW and $\mathrm{AABW}$ give the total mean transports of these water masses south of $1{ }^{\circ} \mathrm{N}$. The transports for LNADW-old water mass and Labrador Sea water (LSW) also refer to the region between the Brazilian coast and $1^{\circ} \mathrm{N}$, because for these water masses no special features in the velocity fields could be found, but the mean transports are relatively persistent. Therefore they have been framed. The SUNADW is split in four different regions as described in the text, and the numbers represent the mean transport and standard deviation within these regions.

equatorial region suggest [Weiss et al., 1985; Kawase and Sarmiento, 1986] that the upper NADW splits into two main cores, one following the coastline of South America and the other part flowing parallel to the equator. Model calculations of Böning and Schott [1993] yielded seasonal reversing eastward and westward transports with only a small mean annual eastward transport. The latter was sufficient to maintain the salinity tongue. The tracks of SOFAR floats [Richardson and Schmitz, 1993] also show reversing equatorial currents with timescales of the order of months. The high variability in the equatorial band in our data is consistent with these float observations, but our observed mean flow is directed to the east.

The total transport values of SUNADW south of $2^{\circ} \mathrm{N}$ vary from $+15.3 \mathrm{~Sv}$ to $-12.3 \mathrm{~S}$, thus no sensible mean can be given. This is not surprising owing to the flow reversals present north of $1^{\circ} 50^{\prime} \mathrm{S}$ in the equatorial band. In our data the reversal does not seem to occur seasonally, but from observations at only three different times this cannot be proven with confidence. The net eastward transport south of this highly variable region is estimated to $11.1 \pm 5.6 \mathrm{~Sv}$, with only a small amount topographically trapped at the coast. Our main current core between $1^{\circ} 50^{\prime} \mathrm{S}$ and $3^{\circ} 09^{\prime} \mathrm{S}$ was also observed by the only float of Richardson and Schmitz [1993] located in that latitude band. This persistent feature has a transport of $9.7 \pm 3.3 \mathrm{~Sv}$.

OLNADW flow cores. The second layer with large velocity and tracer signals is the OLNADW at about $3800 \mathrm{~m}$ depth. At $35^{\circ} \mathrm{W}$ the most persistent and prominent feature in the lower part of the DWBC is the eastward flow of OL- 


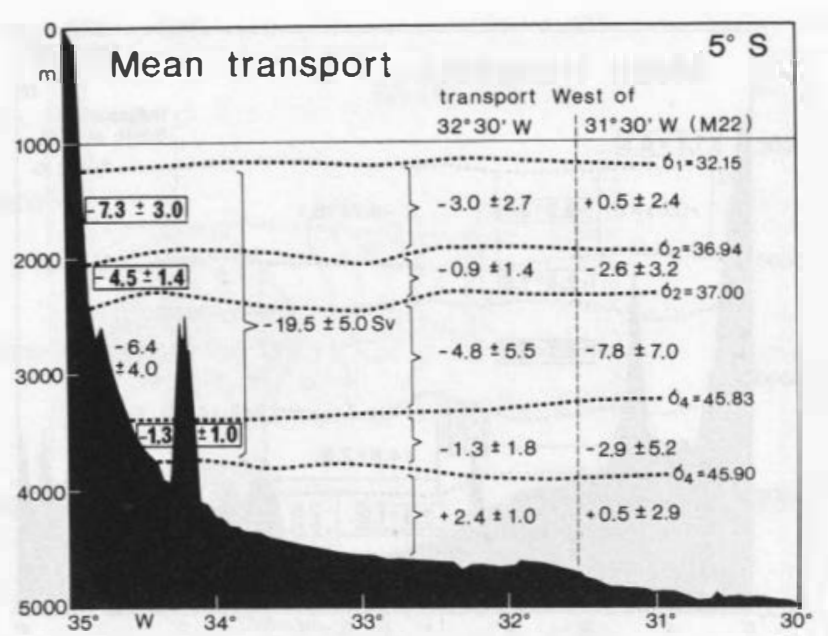

Figure 10. Transport estimates (in sverdrups) for the various deepwater masses at $5^{\circ} \mathrm{S}$ shown for the discussed flow regimes. The mean and standard deviations are calculated from the individual computations presented in the appendix. Features, which are relatively persistent, are in bold numbers and framed. The flow reversal was observed to occur at different locations as follows: $32^{\circ} 59^{\prime} \mathrm{W}$ (October 1990), $34^{\circ} 24^{\prime} \mathrm{W}$ (June 1991, SUNADW), 331' $\mathrm{W}$ (June 1991, other NADW water masses), and $33^{\circ} 50^{\prime} W$ (November 1992). The leftmost numbers give the southward transport of the individual water masses west of the reversal; the mean southward Deep Western Boundary Current (DWBC) transport amounts to $-19.5 \pm 5.0 \mathrm{~Sv}$. The numbers at $32^{\circ} 30^{\prime} \mathrm{W}$ referto the region from the Brazilian coast to $32^{\circ} 30^{\prime} \mathrm{W}$, and they represent the mean transport of the individual water masses west of $32^{\circ} 30^{\prime} \mathrm{W}$. For November 1992 (M22), transport estimates (geostrophy and direct measurements) for the region from the Brazilian coast to $31^{\circ} 30^{\prime} \mathrm{W}$ are also given.

NADW at $1^{\circ} 45^{\prime} S-1^{\circ} 20^{\prime} S$, where the highest F 11 concentrations in this water mass have also been observed. This flow with maximum velocities $>15 \mathrm{~cm} \mathrm{~s}^{-1}$ is topographically guided by the Parnaiba Ridge which exhibits a maximum elevation to about $3000 \mathrm{~m}$ depth just $36 \mathrm{~km}$ west to the section. The flow is concentrated on the northern flank of the ridge with eastward transports between 4.5 and $6.4 \mathrm{~Sv}$. South of the Parnaiba Ridge, the flow of OLNADW is weak and directed mainly to the west. Thus the total OLNADW transport in the equatorial channel $\left(3^{\circ} \mathrm{S}-1^{\circ} \mathrm{N}\right)$ averages to 4.6 $\pm 2.6 \mathrm{~Sv}$.

In May-June 1991, elevated CFM concentrations have also been observed at $0^{\circ} 42^{\prime} \mathrm{N}$, at the northern end of the deep equatorial channel (Figure 3b). This CFM maximum was correlated with a distinct eastward velocity maximum (Figure 6b), leading to an eastward transport of OLNADW north of the equator. This location was not sampled in October 1990. Measurements in November 1992 revealed smaller Fl 1 concentrations than at the Parnaiba Ridge and farther south, with no significant flow indicated in the Pegasus and LADCP velocity profiles. These findings show that OLNADW is also sporadically transported east at the northern edge of the equatorial channel.

LSW, LNADW-old. No clear pattern is evident for the other two NADW water masses (LSW and LNADW-old). However, in May-June 1991 and in November 1992 the flow seems to be influenced by the Parnaiba Ridge, since above that topographic feature, the flow was directed to the east. Although no distinct fiow cores could be found for these two water masses at $35^{\circ} \mathrm{W}$, the overall transport derived from the three cruises (Figure 9) give a consistent picture with eastward transports of $2.8 \pm 1.6 \mathrm{~Sv}$ for LSW and $8.3 \pm 2.1 \mathrm{~Sv}$ for LNADW-old south of $1^{\circ} \mathrm{N}$.

AABW. In the bottom layer the main westward flow of $A A B W$ is located at the southern edge of the equatorial channel between $1^{\circ} 30^{\prime} \mathrm{S}$ and the equator; that is, AABW has not entered the northern hemisphere at that section. In June 1991 and November 1992 the associated eastward velocities are greater than $10-15 \mathrm{~cm} \mathrm{~s}^{-1}$ (Figures $6 \mathrm{~b}$ and $6 \mathrm{c}$ ), in October 1990 the flow of AABW was not well resolved owing to the coarser resolution of the velocity profiles. The mean westward transport of AABW in the equatorial channel amounts to $2.6 \pm 2.0 \mathrm{~Sv}$.

\section{2. $5^{\circ} \mathrm{S}$ Section}

At $5^{\circ} \mathrm{S}$ the flow of the total NADW complex is mainly directed south between the Brazilian coast and about $33^{\circ} 30^{\prime} \mathrm{W}$ (Figures 7 and 8 ). Contrary to the $35^{\circ} \mathrm{W}$ section, the maximum and persistent velocity signals do not coincide exclusively with the water masses with high tracer content; rather, the flow cores here extend vertically over most NADW layers at each horizontal location. East of $33^{\circ} 30^{\prime} \mathrm{W}$, various parts of the NADW coincide with a northward flow, while farther offshore there is another southward flow. Although the flow patterns are essentially the same in October 1990 and November 1992, the off shore locations of the flow reversals change. For SUNADW both the FII and current amplitudes are comparable at the $5^{\circ} \mathrm{S}$ and $35^{\circ} \mathrm{W}$ sections. For instance, in November 1992 the Fll maxima in both section exceeded $0.1 \mathrm{pmol} \mathrm{kg}^{-1}$, and in October 1990 the Fll maxima at $35^{\circ} \mathrm{W}$ were only slightly higher than at $5^{\circ} \mathrm{S}$.

There is little doubt that the observed SUNADW cores actually represent a continuous path from $35^{\circ} \mathrm{W}$ to $5^{\circ} \mathrm{S}$, although the mean transport decreased from $11 \mathrm{~Sv}$ at $35^{\circ} \mathrm{W}$ to $7 \mathrm{~Sv}$ at $5^{\circ} \mathrm{S}$. The situation is different for the deep, high-tracer layer (OLNADW). Both the velocity signal and the Fll concentrations are weaker at $5^{\circ} \mathrm{S}$ compared with $35^{\circ} \mathrm{W}$, despite the short distance between the sections. Additionally, the $\Theta-S$ characteristics change significantly. This indicates either strong mixing or that the OLNADW core observed at $35^{\circ} \mathrm{W}$ at the Parnaiba Ridge does not continue directly to $5^{\circ} \mathrm{S}$ (Figure 11). Therefore in November 1992 we extended the $5^{\circ} \mathrm{S}$ section eastward to $30^{\circ} \mathrm{W}$ in order to test whether or not the seamount chain at $3^{\circ} \mathrm{S}-4^{\circ} \mathrm{S}$ around the Atol das Rocas deflects the LNADW to farther offshore. However, neither the CFM measurements nor the velocity profiles showed a distinct core with elevated values in this offshore region. Thus the fate of the OLNADW core observed at $35^{\circ} \mathrm{W}$ remains an open question. However, high CFM concentrations (C. Andrie, personal communication, 1994) found at the appropriate densities near the Romanche Fracture Zone $\left(0^{\circ} \mathrm{N}, 19^{\circ} \mathrm{W}\right)$ indicate that part of the deep flow also leaves the western boundary current and flows along the equator.

As mentioned above, the southward flow of NADW at $5^{\circ} \mathrm{S}$ near the Brazilian coast is limited to the east by a flow reversal, which occurred in each survey at a different location (between $32^{\circ} 59^{\prime} \mathrm{W}$ and $34^{\circ} 24^{\prime} \mathrm{W}$ ). If one considers only the transport between the coast and the flow reversal, 
then the main contributions to the NADW transport at $5^{\circ} \mathrm{S}$ come from SUNADW $(-7.3 \pm 3.0 \mathrm{~Sv}$ for all surveys) and, in May-June 1991 and November 1992, also from LNADW-old $(-6.4 \pm 4.0 \mathrm{~Sv})$. The estimates for the latter water mass agree with the findings at $35^{\circ} \mathrm{W}$. The SUNADW southward transport of $7.3 \pm 3.3 \mathrm{~Sv}$ is within the error limit of the observed eastward transport south of $1^{\circ} 50^{\prime} \mathrm{S}$ at $35^{\circ} \mathrm{W}(11.1 \pm$ $5.6 \mathrm{~Sv})$.

At $5^{\circ} \mathrm{S}$ west of $32^{\circ} 30^{\prime} \mathrm{W}$, (Figure 10 ) only minor southward transports were observed for OLNADW $(1.3 \pm 1.8 \mathrm{~Sv})$ compared with the southeastward transport of $4.6 \pm 2.6 \mathrm{~Sv}$ at $35^{\circ} \mathrm{W}$. Extending the section to $31^{\circ} 30^{\prime} \mathrm{W}$, a southward transport of $2.9 \pm 5.2 \mathrm{~Sv}$ was obtained. At least the latter result is comparable to the total transports observed at $35^{\circ} \mathrm{W}$ in the equatorial channel (4.6 Sv). One has to bear in mind that owing to the various flow reversals, the estimated transports east of the first flow reversal depend strongly on the location of the eastem limit of the particular section.

\subsection{Circulation Pattern of the DWBC Water Masses in the Equatorial Region}

Despite the observed variability in the data we believe a schematic circulation pattern for the various water masses can be established by combining our mean transports of the DWBC water masses at $35^{\circ} \mathrm{W}, 5^{\circ} \mathrm{S}$, and $10^{\circ} \mathrm{S}$ with transport estimates at $44^{\circ} \mathrm{W}$ [Schott et al., 1993; Molinari et al., 1992] and west of $44^{\circ} \mathrm{W}$ [Molinari et al., 1992] (Figures 12a-12d). We also include the section at $10^{\circ} \mathrm{S}$ which was occupied during the M22 cruise in November 1992. Owing to technical problems, no LADCP measurements exist on this section for the deepwater, and the presented transports are estimated by geostrophic calculations. Note that the section only extended to $32^{\circ} 30^{\prime} \mathrm{W}$, thus the mean southward DWBC transport of $4.7 \mathrm{~Sv}$ at $10^{\circ} \mathrm{S}$ might be incomplete. Friedrichs et al. [1994] calculated a southward DWBC transport of 20.7 Sv at $11^{\circ} \mathrm{S}$ for water with densities between $36.95<\sigma_{2}<37.045$ along a basin-wide section extending to the Mid-Atlantic

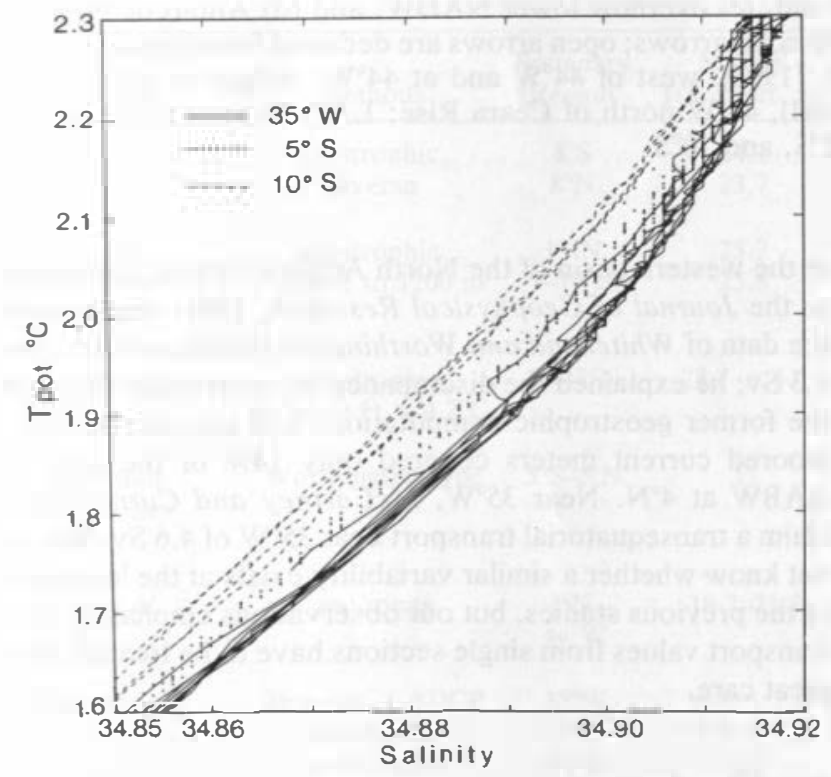

Figure 11. Potential temperature $\Theta$-salinity (S) diagrams for OLNADW at $35^{\circ} \mathrm{W}$ (solid lines), $5^{\circ} \mathrm{S}$ (dots), and $10^{\circ} \mathrm{S}$ (dashed lines) in November 1992.
Ridge. For consistency with our measurements at $5^{\circ} \mathrm{S}$ and at $35^{\circ} \mathrm{W}$ we used our own estimates for $10^{\circ} \mathrm{S}$. In our schematic drawing (Figure 12) the observations are presented in solid arrows and they have been complemented by the open arrows, calculated from mass balance considerations. Although LSW and LNADW-old differ in the formation process and region, they have been combined because of their similar flow field near the equator (Figure 12b).

SUNADW. The eastward transport of SUNADW in the boundary current seems to increase from $4 \mathrm{~Sv}$ west of $45^{\circ} \mathrm{W}$ to $11 \mathrm{~Sv}$ at $35^{\circ} \mathrm{W}$ (neglecting the highly variable flow of -10 $\pm 18 \mathrm{~Sv}$ at $35^{\circ} \mathrm{W}$ north of $1^{\circ} 50^{\prime} \mathrm{S}$ ). This flow pattern could be caused by various recirculation paths of SUNADW. Recirculation was also indicated by the CFM and salinity distributions as well as by the float data of Richardson and Schmitz [1993]. South of the equator, we observed a decrease in the transport estimates from $7 \mathrm{~Sv}$ at $5^{\circ} \mathrm{S}$ to $3 \mathrm{~Sv}$ at $10^{\circ} \mathrm{S}$. Owing to the limited spatial extent of this section, we cannot decide whether the missing $4 \mathrm{~Sv}$ at $10^{\circ} \mathrm{S}$ east of $32^{\circ} 30^{\prime} \mathrm{W}$ flow south or whether they are carried to the east into the interior of the basin.

LSW and LNADW-old. The transport estimates of LSW and LNADW-old west of $43^{\circ} \mathrm{W}$ almost doubled from 5 to 6 $\mathrm{Sv}$ to $11 \mathrm{~Sv}$ at $35^{\circ} \mathrm{W}$. Altogether, $11 \mathrm{~Sv}$ were observed at $5^{\circ} \mathrm{S}$, with $6 \mathrm{~Sv}$ flowing south in the boundary current itself; the estimates east of the boundary current add up to a southward transport of $5 \mathrm{~Sv}$. At $10^{\circ} \mathrm{S}$ no net transport of these two water masses was found. Again, the fact that our measurements at $10^{\circ} \mathrm{S}$ were restricted to the region west of $32^{\circ} 30^{\prime} \mathrm{W}$ and the fact that this section was only occupied once lead to uncertainties regarding the circulation which makes it difficult to explain the missing $11 \mathrm{~Sv}$.

OLNADW. To the west, at $44^{\circ} \mathrm{W}$, current meter moorings [Schott et al., 1993] yielded a mean transport of $4.5 \mathrm{~Sv}$ (NADW below $3100 \mathrm{~m}$ ) south of Ceara Rise $\left(44^{\circ} \mathrm{W}, 5^{\circ} \mathrm{N}\right)$, which is comparable to our findings at $35^{\circ} \mathrm{W}$. Other transport estimates in the tropical and subtropical Atlantic are much higher than our transports [Molinari et al., 1992; Speer and McCartney, 1991] $13.2 \mathrm{~Sv}$ at $7^{\circ} \mathrm{N}$ to $10^{\circ} \mathrm{N}$ for $2900-4400 \mathrm{~m}$ ). The $13 \mathrm{~Sv}$ of OLNADW transports reported by Molinari et al. [1992] are computed mostly from sections west of $44^{\circ} \mathrm{W}$. The authors stated that the Ceara Rise at $44^{\circ} \mathrm{W}$ probably blocks some of the deep flow and causes a recirculation. The region north of the Ceara Rise was not covered by the moorings at $44^{\circ} \mathrm{W}$. However, in November 1992, direct velocity measurements there yielded a transport of about 7 Sv of OLNADW to the east (J. Fischer, personal communication, 1994). In November 1992 this flow did not appear at $35^{\circ} \mathrm{W}$ (Figure 12). This indicates that a part of the larger transports westward at $44^{\circ} \mathrm{W}$ forms a recirculation cell west of $35^{\circ} \mathrm{W}$ and north of the Ceara Rise.

NADW. The total eastward transport of the four water masses at $35^{\circ} \mathrm{W}$ resulted in $26.8 \pm 7.0 \mathrm{~Sv}$, if one neglects for SUNADW the highly variable zone north of $1^{\circ} 50^{\prime} \mathrm{S}$. The total southward transport of the four water masses of the DWBC west of the flow reversal at $5^{\circ} \mathrm{S}$ is $19.5 \pm 5.3 \mathrm{~Sv}$. This transport rate at $35^{\circ} \mathrm{W}$ for NADW agrees with earlier observations made to the northwest of our study area (Table 2), but the large standard deviation indicates the large variability between single realizations. The Table 6 results show that the southward flow of NADW as a boundary current at $5^{\circ} \mathrm{S}$ is reduced by about $7 \mathrm{~Sv}$, and at $10^{\circ} \mathrm{S}$ west of $32^{\circ} 30^{\prime} \mathrm{W}$ only 4.7 Sv are found. We cannot decide whether the difference is 

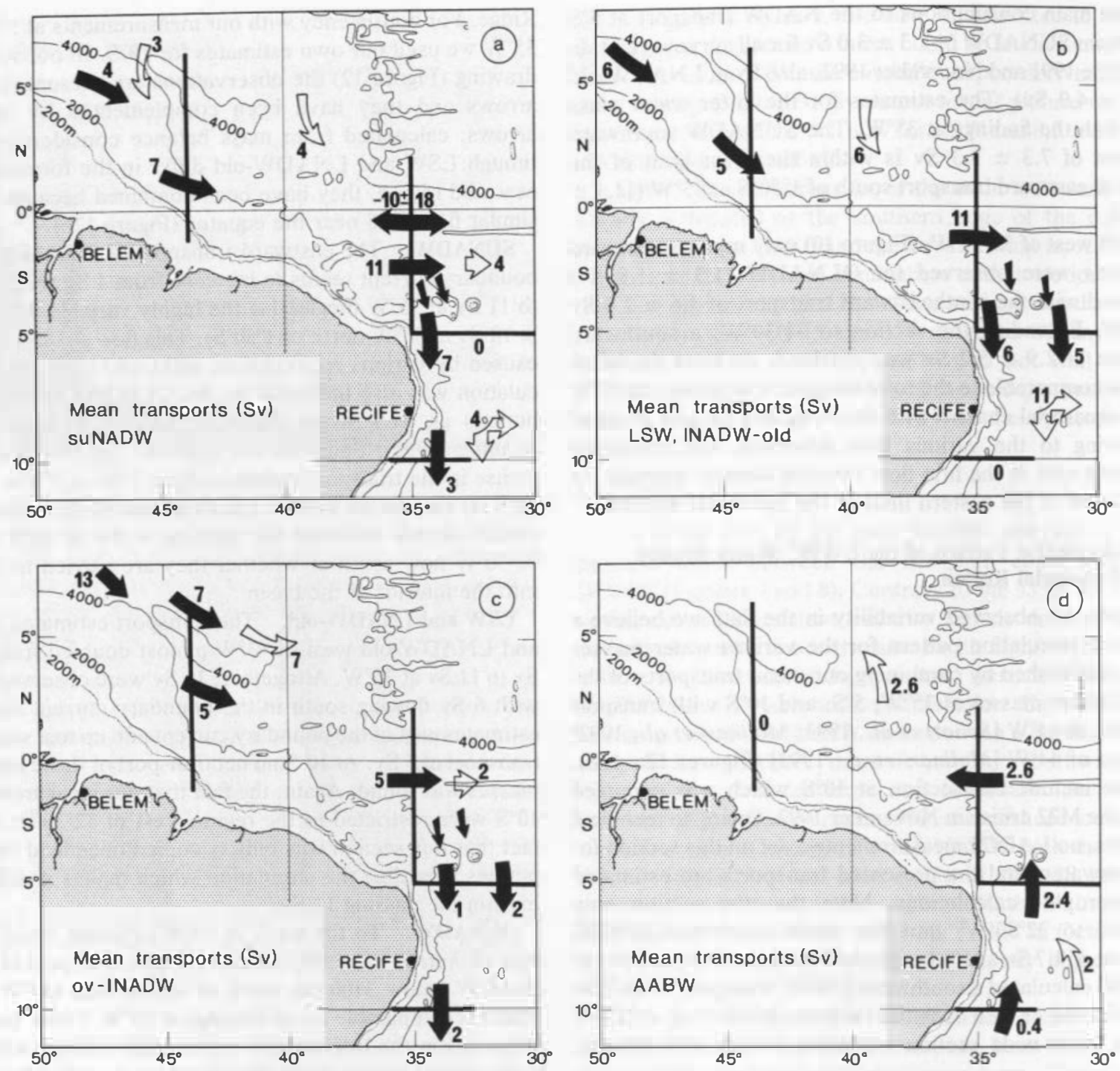

Figure 12. Circulation patterns and transports (in sverdrups) of the DWBC water masses (a) shallow upper NADW, (b) combined LSW and lower NADW-old, (c) overflow lower NADW, and (d) Antarctic Bottom Water. The observed estimates are presented by solid arrows; open arrows are deduced from mass balance considerations. Data are from Molinari et al. [1992], west of $44^{\circ} \mathrm{W}$ and at $44^{\circ} \mathrm{W}$; Schott et al. [1993], 44 ${ }^{\circ} \mathrm{W}$; J. Fischer (personal communication, 1994), $44^{\circ} \mathrm{W}$ north of Ceara Rise; LADCP measurements in October 1992 (M22); and this study, $35^{\circ} \mathrm{W}, 5^{\circ} \mathrm{S}$, and $10^{\circ} \mathrm{S}$.

due to the unresolved high temporal variability of the flow or if after crossing the equator, a real reduction takes place by recirculation or an eastward flow along the equator (Figure 12).

AABW. At $35^{\circ} \mathrm{W}$ the main transport of the AABW (Figure $12 \mathrm{~d}$ ) occurs south of the equator and is directed to the west. The magnitudes $(2.6 \pm 2.0 \mathrm{~Sv})$ have to be compared with previous estimates in the tropical region and to the transports calculated at $5^{\circ} \mathrm{S}(2.4 \pm 1.0 \mathrm{~Sv})$ and at $10^{\circ} \mathrm{S}(0.4$ $\mathrm{Sv}$ ). Along $8^{\circ} \mathrm{S}$ and $8^{\circ} \mathrm{N}$ the northward transport of AABW has been calculated by Wright [1970] to be of the order of 2 to 3 Sv. Whitehead and Worthington [1982] used moorings at $4^{\circ} \mathrm{N}$ between the Ceara Rise and the Mid-Atlantic Ridge to estimate a mean transport into the North Atlantic of $0.8 \mathrm{~Sv}$ of water colder than $1.9^{\circ} \mathrm{C}$. However, from geostrophic computations they obtained a value of $1.98 \mathrm{~Sv}$. M. S. McCartney (The transport of Antarctic bottom water at $4^{\circ} \mathrm{N}$ in the western basin of the North Atlantic Ocean, submitted to the Journal of Geophysical Research, 1994) reevaluated the data of Whitehead and Worthington [1982] and obtained 4.3 Sv; he explained the discrepancy by systematic errors in the former geostrophic computations and argued that their moored current meters covered only $14 \%$ of the area of $\mathrm{AABW}$ at $4^{\circ} \mathrm{N}$. Near $35^{\circ} \mathrm{W}$, McCartney and Curry [1993] claim a transequatorial transport near $35^{\circ} \mathrm{W}$ of $4.6 \mathrm{~Sv}$. We do not know whether a similar variability exists at the locations of the previous studies, but our observations emphasize that transport values from single sections have to be treated with great care.

\section{Conclusions}

The CFM distributions and the hydrographic measurements enabled us to identify four different water masses 
forming the NADW system and to establish water mass boundaries suitable for the observed regions. They deviate partly from previously published investigations.

Direct and geostrophic current measurements have been used for plotting sections and for estimating transports. The methods partly complement each other, since geostrophy breaks down near the equator, while the station resolution of the direct measurements was too coarse in some instances. At $5^{\circ} \mathrm{S}$ a comparison of the two methods was possible, and the transports in June 1991 for the various deepwater masses differed only by 0.2 to $2.0 \mathrm{~Sv}$, which is smaller than the differences between the individual cruises. However, greater discrepancies have been found to occur at $5^{\circ} \mathrm{S}$ east of the boundary current. Both our three visits to the region and the mooring data at $44^{\circ} \mathrm{W}$ [Schott et al., 1993] show that the temporal variability of the velocity field in the region of interest is high. Therefore our three realizations of the flow field are not likely to reflect the long-term mean transport, and one has to be cautious in their interpretation. Nevertheless, the flow pattern at $35^{\circ} \mathrm{W}$ and at $5^{\circ} \mathrm{S}$ shows some features which seem to be persistent.

At $35^{\circ} \mathrm{W}$ the water masses with high CFM values exhibit the highest velocity signals. The flow cores of the individual water masses do not extend vertically over several layers but are found at different horizontal locations. In contrast to the DWBC at $44^{\circ} \mathrm{W}$ [Schott et al., 1993], the main transport of SUNADW and LSW is not trapped to the coast but occurs about $320 \mathrm{~km}$ off shore.

The flow pattern of the high tracer OLNADW is guided by the Parnaiba Ridge $\left(1^{\circ} 45^{\prime} \mathrm{S}, 35^{\circ} \mathrm{W}\right)$, where the highest velocities and also the highest CFM concentrations have been found. In addition, it was observed at the northem edge of the equatorial channel that a sporadic transport of OLNADW occurs. The differences of the CFM signals and the $\Theta-S$ characteristic between the $35^{\circ} \mathrm{W}$ and the $5^{\circ} \mathrm{S}$ section

Table 2. Estimates of NADW Transports Near the Equator

\begin{tabular}{|c|c|c|c|}
\hline Reference & Methods & $\begin{array}{l}\text { Boundary } \\
\text { Region }\end{array}$ & $\begin{array}{c}\text { NADW } \\
\text { Transport, Sv }\end{array}$ \\
\hline Roemmich [1983] & $\begin{array}{c}\text { geostrophic, } \\
\text { inverse }\end{array}$ & $\begin{array}{l}8^{\circ} \mathrm{S} \\
8^{\circ} \mathrm{N}\end{array}$ & $\begin{array}{l}24.1 \\
23.7\end{array}$ \\
\hline $\begin{array}{l}\text { Speer and } \\
\text { McCartney } \\
\text { [1992] }\end{array}$ & $\begin{array}{l}\text { geostrophic, } \\
\text { relative to } 1200 \mathrm{~m}\end{array}$ & $\begin{array}{c}13^{\circ} \mathrm{N} \\
7-10^{\circ} \mathrm{N}\end{array}$ & $\begin{array}{l}25.2 \\
25.8\end{array}$ \\
\hline $\begin{array}{l}\text { Molinari et al. } \\
\text { [1992] }\end{array}$ & $\begin{array}{l}\text { geostrophic, } \\
\text { relative } \Theta=4.7^{\circ} \mathrm{C}\end{array}$ & $2^{\circ}-12^{\circ} \mathrm{N}$ & $23.7 \pm 4.0$ \\
\hline $\begin{array}{l}\text { Schmitz and } \\
\text { McCartney } \\
\text { [1993] }\end{array}$ & Worthington type & $5^{\circ} \mathrm{S}-5^{\circ} \mathrm{N}$ & 17 \\
\hline $\begin{array}{l}\text { Schott et al. } \\
\text { [1993] }\end{array}$ & moorings & $\begin{array}{l}1^{\circ} \mathrm{N} \\
44^{\circ} \mathrm{W}\end{array}$ & $18.7-21.8$ \\
\hline This study & $\begin{array}{l}\text { Pegasus, LADCP } \\
\text { geostrophic } \\
\text { geostrophic }\end{array}$ & $\begin{array}{c}35^{\circ} \mathrm{W} \\
5^{\circ} \mathrm{S} \\
10^{\circ} \mathrm{S}\end{array}$ & $\begin{array}{c}26.8 \pm 7.0 \\
19.5 \pm 5.3 \\
4.7\end{array}$ \\
\hline $\begin{array}{l}\text { Friedrichs et al. } \\
\text { [1994] }\end{array}$ & $\begin{array}{c}\text { geostrophic } \\
\text { without SUNADW }\end{array}$ & $11^{\circ} \mathrm{S}$ & 20.7 \\
\hline
\end{tabular}

suggest that a major modification of this water mass occurs between the two sections.

The velocity fields of the various NADW water masses at $5^{\circ} \mathrm{S}$ are more vertically coherent than at $35^{\circ} \mathrm{W}$, and the highest velocity signals are not restricted to the water masses with a high CFM concentrations. The main southward flow occurs near the coast, and it is limited off shore by a reverse flow, which was present on all three cruises but at different locations.

The calculated transports for NADW $(26.8 \pm 7.0 \mathrm{~Sv}$ at $35^{\circ} \mathrm{W}$ and $-19.5 \pm 5.3 \mathrm{~Sv}$ at $\left.5^{\circ} \mathrm{S}\right)$ and for AABW $(-2.6 \pm 2.0$ $\mathrm{Sv}$ at $35^{\circ} \mathrm{W}, 2.4 \pm 1.0 \mathrm{~Sv}$ at $5^{\circ} \mathrm{S}$ ) are in the range of previously published estimates but show the important influence of temporal and spatial variability. Nevertheless, we combined the estimated mean transports of the DWBC water masses from the north and south to suggest circulation patterns for the water masses near the equator.

\section{Appendix}

In the following we explain and give the detailed estimates for the transports of the discussed water masses at the $35^{\circ} \mathrm{W}$ and the $5^{\circ} \mathrm{S}$ sections. This will include and, where possible, combine the estimates derived from the various methods available.

Table Al contains the transports of the SUNADW at the $35^{\circ} \mathrm{W}$ section, positive values to the east. The transport for the different parts of the section is given separately here owing to the presence of several flow cores. Geostrophic transports $(G)$ and direct measurements (D) are listed sepa rately. The transports for all deepwater masses at $35^{\circ} \mathrm{W}$ is then given in Table A2, without division of the section into separate pieces.

Tables A3 and A4 give the corresponding transports for the $5^{\circ} \mathrm{S}$ section, with positive values to the north. Because of the alternating bands of currents in that section, Table A3 first shows the results including only the region west of the

Table A1. Transport Estimates for Shallow, Upper NADW at $35^{\circ} \mathrm{W}$ for the Discussed Flow Regimes

\begin{tabular}{|c|c|c|c|c|}
\hline & South $4^{\circ} 30^{\prime} \mathrm{S}$ & $4^{\circ} 30^{\prime} \mathrm{S}-3^{\circ} 10^{\prime} \mathrm{S}$ & $3^{\circ} 10^{\prime} \mathrm{S}-1^{\circ} 50^{\prime} \mathrm{S}$ & $1^{\circ} 50^{\prime} \mathrm{S}-2^{\circ} \mathrm{N}$ \\
\hline M14* & $+0.5 \mathrm{G}$ & $+6.9 \mathrm{G}$ & $\cdots$ & $+\cdots$ \\
\hline M14 & $\cdots$ & $*$ & $+6.8 \mathrm{D}$ & $-11.6 \mathrm{D}$ \\
\hline M16 & $+1.6 \mathrm{G}$ & $-0.5 \mathrm{G}$ & $\ldots$ & $\ldots$ \\
\hline M16 & $+1.5 \mathrm{D}$ & $-1.4 \mathrm{D}$ & $+13.3 \mathrm{D}$ & $-26.7 \mathrm{D}$ \\
\hline $\mathrm{M} 22 \dagger$ & $\cdots$ & $+3.2 \mathrm{G}$ & $\cdots$ & … \\
\hline M22 & $+0.8 \mathrm{D}$ & $-3.8 \mathrm{D}$ & $+9.0 \mathrm{D}$ & +9.3 D \\
\hline
\end{tabular}

*Direct estimates at the M14 cruise are not available due to the coarse spatial resolution of the velocity profiles. All values are in sverdrups. $G$ is calculated from geostrophic computations. The reference level is density $\sigma_{4}=45.90$; if the profiles do not reach this density level, $\sigma_{1}=32.15$ is used. $\mathrm{D}$ is calculated from the velocity field obtained by direct measurements. Geostrophic computations are only applied south of $3^{\circ} 10^{\prime} \mathrm{S}$.

†Geostrophic computations for the November 1992 (M22) south of $4^{\circ} 30^{\prime} \mathrm{S}$ could not be carried out because the stations near the coast did not reach the reference level. The direct and geostrophic estimates between $4^{\circ} 30^{\prime} \mathrm{S}$ and $3^{\circ} 10^{\prime} \mathrm{S}$ at M22 contradict each other; the geostrophic-derived eastward transports for all deepwater masses at M22 are dominated from the station pair at $3^{\circ} 09^{\prime} \mathrm{S}$ and $3^{\circ} 29^{\prime} \mathrm{S}$, so, most likely, the chosen reference levels are not suitable for these two stations. 
Table A2. Transport Estimates for Deepwater Masses at $35^{\circ} \mathrm{W}$ for the Discussed Flow Regimes

\begin{tabular}{ccccccc}
\hline & LNADW & & \multicolumn{3}{c}{ AABW } \\
total & $\begin{array}{c}\text { Old } \\
\text { Total }\end{array}$ & $\begin{array}{c}\text { OLNADW, } \\
\text { Panaiba }\end{array}$ & Total & $\begin{array}{c}\text { South of } \\
\text { Equator }\end{array}$ & Total \\
\hline $\mathrm{M} 44+4.6 \mathrm{G}+\mathrm{D}$ & $\begin{array}{c}+10.7 \\
\mathrm{G}+\mathrm{D}\end{array}$ & $+4.5 \mathrm{D}$ & $+5.5 \mathrm{D}$ & $-0.6 \mathrm{D}$ & $-0.7 \mathrm{D}$ \\
$\mathrm{M} 16+1.6 \mathrm{G}+\mathrm{D}$ & $\begin{array}{c}+7.5 \\
\mathrm{G}+\mathrm{D}\end{array}$ & $+6.4 \mathrm{D}$ & $+6.6 \mathrm{D}$ & $-4.3 \mathrm{D}$ & $-4.6 \mathrm{D}$ \\
$\mathrm{M} 22$ & $+2.3 \mathrm{D}$ & $+6.7 \mathrm{D}$ & $+4.5 \mathrm{D}$ & $+1.6 \mathrm{D}$ & $-2.8 \mathrm{D}$ & $-2.6 \mathrm{D}$
\end{tabular}

All values are in sverdrups. Water mass abbreviations are same as Table 1. G and D are same as Table 2. G + D is south of $3^{\circ} 09^{\prime} \mathrm{S}$ geostrophic computations; north of it, derived from direct velocity measurements. Total transports refer to the region from the Brazilian coast to $1^{\circ} \mathrm{N}$ (Ml4 cruise) or $2^{\circ} \mathrm{N}$ (MI6 and M22 cruises).

Table A3. Transport Estimates for the Various Deepwater Masses at $5^{\circ} \mathrm{S}$, West of the Flow Reversal

\begin{tabular}{lccccc}
\hline & SUNADW & LSW & $\begin{array}{c}\text { LNADW } \\
\text { Old }\end{array}$ & $\begin{array}{c}\text { LNADW } \\
\text { Overflow }\end{array}$ & $\begin{array}{c}\text { NADW } \\
\text { Total }\end{array}$ \\
\hline M14 G & -12.1 & -2.8 & -0.6 & -0.7 & -16.2 \\
M16 G & -4.1 & -3.6 & -5.4 & -1.5 & -14.6 \\
M16 D & -6.9 & -4.4 & -5.7 & -0.1 & -17.1 \\
M22 G & -5.8 & -5.7 & -9.7 & -1.3 & -22.5 \\
M22 R & -2.8 & -3.3 & -11.8 & -3.6 & -21.5 \\
M22 D & -7.8 & -6.0 & -10.7 & -2.9 & -27.4 \\
M22 K & -7.2 & -6.2 & -15.1 & -3.6 & -32.1 \\
\hline
\end{tabular}

The flow reversal occurred at different locations as follows:

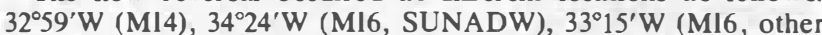
NADW water masses), and $33^{\circ} 40^{\prime} \mathrm{W}$ or $34^{\circ} \mathrm{W}$ (M22, depending on the reference level chosen).

See Tables 1 and 2 for definitions and units. $K$ indicates geostrophic computations adjusted to the mean velocities between 150 and $1000 \mathrm{~m}$ derived from the LADCP profiles (only for M22); R, calculated from geostrophic computations with the reference level $\sigma_{1}=32.15$ (only M22).

Table A4. Transport Estimates of the Various Deepwater Masses at $5^{\circ} \mathrm{S}$

\begin{tabular}{|c|c|c|c|c|c|c|}
\hline & SUNADW & LSW & $\begin{array}{l}\text { NADW } \\
\text { Old }\end{array}$ & OLNADW & AABW & $\begin{array}{c}\text { NADW } \\
\text { Total }\end{array}$ \\
\hline \multicolumn{7}{|c|}{ Brazilian Coast to $32^{\circ} 30^{\prime} \mathrm{W}$} \\
\hline M14 G & -2.3 & +0.6 & +3.0 & -0.3 & +1.7 & +1.0 \\
\hline M16 G & -6.6 & -1.3 & -2.7 & -0.4 & +2.3 & -11.0 \\
\hline M16 D & -4.6 & -3.1 & -4.1 & +0.3 & +4.1 & -11.5 \\
\hline M22 G & +2.0 & -1.1 & -6.2 & -1.4 & -1.9 & -6.7 \\
\hline M22 R & 1.0 & 0.1 & -6.9 & -2.6 & +3.6 & -8.4 \\
\hline M22 D & 0.4 & -4.8 & -10.6 & -4.2 & -2.0 & -19.2 \\
\hline M22 K & -1.7 & -2.7 & -9.6 & -1.8 & -1.8 & -15.8 \\
\hline \multicolumn{7}{|c|}{ Brazilian Coast to $31^{\circ} 30^{\prime} \mathrm{W}$} \\
\hline M22 G & +2.8 & -0.3 & -3.5 & -1.3 & -0.5 & -2.3 \\
\hline M22 R & +2.6 & 2.2 & -3.3 & -2.2 & +6.0 & -0.7 \\
\hline M22 D & -1.2 & -4.8 & -12.8 & -6.6 & -1.6 & -25.4 \\
\hline M22 K & +2.2 & -0.3 & -2.8 & +0.8 & +2.5 & -0.1 \\
\hline
\end{tabular}

Reference levels and notations (D, G, K, R) are as in Table A3. flow reversal. Both direct and geostrophic estimates are included again, but some different means of referencing were used for the latter in the case of cruise M22, either the geostrophic flows were adjusted to the 150 - to 1000 -m mean derived from the LADCP profiles (indicated by $\mathrm{K}$ ) or a reference level of $\sigma_{1}=32.15$ was used. Table $\mathrm{A} 4$ shows the transports at $5^{\circ} \mathrm{S}$ for the whole length of the sections measured. During the earlier cruises this was from the Brazilian coast to $32^{\circ} 30^{\prime} \mathrm{W}$; the last cruise (M22) extended the section to $31^{\circ} 30^{\prime} \mathrm{W}$. Therefore all transports are first given for the former limit, and the M22 values are then given, in addition, for the complete section.

Acknowledgments. We thank the captains and the crews of the research vessel Meteor for their help, and C. Meinke, U. Papenburg, and M. Elbrächter for technical assistance. J. Fischer made the lowered ADCP system operational at IfM Kiel and the data available to us. We appreciate the assistance of G. Krahmann and U. Gartemicht in mapping and contouring the data and of A. Eisele who drafted the figures. Thanks to M. Visbeck, J. Fischer, and F. Schott for enlightening discussions. Financial support of the Deutsche Forschungsgemeinschaft (DFG) and of the Bundesministerium für Forschung and Technologie (BMFT) is gratefully acknowledged.

\section{References}

Böning, C., and F. Schott, Deep currents and the eastward salinity tongue in the equatorial Atlantic: Results from an eddy-resolving, primitive equation model, J. Geophys. Res., 98, 6991-6999, 1993.

Bryden, H. L., and M. M. Hall, Heat transport by currents across $25^{\circ} \mathrm{N}$ in the Atlantic Ocean, Science, 207, 884-886, 1980.

Bullister, J. L., Chlorofluorocarbons as time-dependent tracers in the oce an, Oceanography, 2, 12-17, 1989.

Bullister, J. L., and R. F. Weiss, Determination of $\mathrm{CCl} 3 \mathrm{~F}$ and CCI2F2 in seawater and air, Deep Sea Res., Part A, 35, 839-853, 1988.

Fine, R. A., and R. L. Molinari, A continuous deep western boundary current between Abaco $\left(26.5^{\circ} \mathrm{N}\right)$ and Barbados $\left(13^{\circ} \mathrm{N}\right)$, Deep Sea Res., Part A, 35, 1441-1450, 1988.

Fischer, J., and M. Visbeck, Deep velocity profiling with selfcontained ADCPs, J. Atmos. Oceanic Technol., 10, 764-773, 1993.

Friedrichs, M. A. M., M. S. McCartney, and M. M. Hall, Hemispheric asymmetry of deep water transport modes in the Atlantic, J. Geophys. Res., in press, 1994.

Gascard, J.-C., and R. A. Clarke, The formation of Labrador Sea water, II, Mesoscale and smaller scale processes, J. Phys. Oceanogr., 13, 1779-1797, 1983.

Grasshoff, K., M. Ehrhardt, and K. Kremling (Eds.), Methods of Seawater Analysis, 419 pp., Verlag Chemie, Weinheim, Ger many, 1983.

Hall, M. M., and H. L. Bryden, Direct estimates and mechanisms of ocean heat transport, Deep Sea Res., Part A, 29, 339-359, 1982.

Kawase, M., and J. L. Sarmiento, Circulation and nutrients in middepth Atlantic waters, J. Geophys. Res., 91, 9749-9770, 1986.

Lazier, J. R., The renewal of Labrador Sea water, Deep Sea Res., 20, 341-353, 1973

Lazier, J. R., Temperature and salinity changes in the deep Labrador Sea, 1962-1986, Deep Sea Res., Part A, 35, 1247-1253, 1988.

McCartney, M. S., and R. A. Curry, Trans-equatorial flow of Antarctic Bottom Water in the western Atlantic Ocean: Abyssal geostrophy at the equator, J. Phys. Oceanogr., 23, 1264-1276, 1993.

Molinari, R. L., R. A. Fine, and E. Johns, The deep western boundary current in the western tropical North Atlantic Ocean, Deep Sea Res., Part A, 39, 1967-1984, 1992.

Owens, W. B., and R. C. Millard, A new algorithm for CTD oxygen calibration, J. Phys. Oceanogr., 15, 621-631, 1985.

Pickart, R. S., Water mass components of the North Atlantic deep western boundary current, Deep Sea Res., Part A, 39, 1553-1572, 1992.

Reid, J. L., On the total geostrophic circulation of the South 
Atlantic Ocean: Flow pattern, tracers and transports, Prog. Oceanogr., 23, 149-244, 1989.

Reid, J. L., A preliminary view of the deep circulation of the North Atlantic Ocean (abstract), Eos Trans. AGU, 7I, 1387, 1990.

Rhein, M., Ventilation rates of the Greenland and Norwegian Seas derived from distributions of the chlorofuoromethanes F11 and F12, Deep Sea Res., Part A, 38, $485503,1991$.

Rhein, M., The deep western boundary current: Tracers and velocit ies, Deep Sea Res., 4I, Part I, 263-281, 1994.

Rhein, M., Deep water formation in the western Mediterranean, $J$. Geophys. Res., in press, 1995.

Richard son, P. L., and W. J. Schmitz Jr., Deep cross-equatorial flow in the Atlantic measured with SOFAR floats, J. Geophys. Res., 98, 8371-8387, 1993.

Roemmich, D., Estimation of meridional heat flux in the North Atlantic by inverse method, J. Phys. Oceanogr., 10, 1972-1983, 1980.

Roemmich, D., The balance of geostrophic and Ekman transports in the tropical Atlantic Ocean, J. Phys. Oceanogr., 13, 1534-1539, 1983.

Schlitzer, R., Modeling the nutrient and carbon cycles of the North Atlantic, 1, Circulation, mixing coefficients, and heat fluxes, $J$. Geophys. Res., 93, 10,699-10,723, 1988.

Schmitz, W. J. Jr., and M. S. McCartney, On the North Atlantic circulation, Rev. Geophys., 31, 29-49, 1993.

Schott, F., J. Fischer, J. Reppin, and U. Send, On mean and seasonal currents and transports at the westem boundary of the equatorial Atlantic, J. Geophys. Res., 98, 14,353-14,368, 1993.

Send, U., Accuracy of current profile measurements: Effect of tropical and midlatitude internal waves, J. Geophys. Res., 99, 16,229-16,236, 1994.

Send, U., and J. Marshall, Integral effects of deep convection, $J$. Phys. Oceanogr., in press, 1994.

Smethie, W. M., and J. H. Swift, The tritium:krypton-85 age of Denmark Strait overflow water and Gibbs Fracture Zone water just south of Denmark Strait, J. Geophys. Res., 94, 8265-8275, 1989.

Spain, P. F., D. L. Dorson, and H. T. Rossby, PEGASUS: A simple acoustically tracked velocity profiler, Deep Sea Res., Part A, 28, 1553-1567, 1981

Speer, K. G., and M. S. McCartney, Tracing lower North Atlantic deep water across the equator, J. Geophys. Res., 96, 20,44320,448, 1991.

Stramma, L., Geostrophic tr ansport of the South Equatorial Current in the Atlantic, J. Mar. Res., 49, 281-294, 1991.

Sverdrup, H. U., M. W. Johnson, and R. H. Fleming, The Oceans, Their Physics, Chemistry and General Biology, 1087 pp., Prentice Hall, Englewood Cliffs, N. J., 1942.

Talley, L. D., and M. S. McCartney, Distribution and circulation of Labrador Sea water, J. Phys. Oceanogr., 12, 1189-1205, 1982.

Tchernia, P., Descriptive Regional Oceanography, Pergamon Marine Ser., vol. 3, 253 pp., Pergamon, New York, 1980.

Warner, M. J., and R. F. Weiss, Solubilities of chlorofluorocarbons 11 and 12 in water and seawater, Deep Sea Res., Part A, 32, 1485-1497, 1985.

Watts, D. R., Equatorwards currents in the temperature range $2^{\circ}-6^{\circ} \mathrm{C}$ on the continental slope, Mid Atlantic Bight, in Deep Water Convection and Deep Water Formation, edited by $\mathrm{H}$. Chu and E. Charnock, pp. 183-196, Elsevier, New York, 1990.

Weiss, R. F., J. L. Bullister, R. H. Gammon, and M. J. Warner, Atmospheric chlorofluoromethanes in the deep equatorial Atlantic, Nature, 314, 608-610, 1985.

Whitehead, J. A. Jr., and L. V. Worthington, The flux and mixing rates of Antarctic Bottom Water within the North Atlantic, $J$. Geophys. Res., 87, 7903-7924, 1982.

Wright, W. R., Northward transport of Antarctic Bottom Water in the western Atlantic Ocean, Deep Sea Res., 17, 367-371, 1970.

Wunsch, C., and B. Grant, Towards the general circulation of the North Atlantic Ocean, Prog. Oceanogr., 11, 1-59, 1982.

M. Rhein, U. Send, L. Stramma, Institut für Meereskunde an der Universität Kiel, Düstembrooker Weg 20, 24105 Kiel, Germany. (e mail: mrhein@ifm.uni-kiel.d400.de)

(Received August 3, 1993; revised July 18, 1994; accepted August 1, 1994.) 